\title{
Hydrodynamic Modelling of Floods and Estimating Socio-economic Impacts of Floods in Ugandan River Malaba Sub-catchment
}

\author{
Ambrose Mubialiwo ${ }^{1,2}$ (D) Adane Abebe $^{1,3}$ (D) Nafyad Serre Kawo ${ }^{4}$ (D) Job Ekolu ${ }^{5} \cdot$ Saralees Nadarajah $^{6}$ (D) \\ Charles Onyutha ${ }^{2}$ iD
}

Received: 9 August 2021 / Revised: 15 November 2021 / Accepted: 17 November 2021 / Published online: 1 January 2022

(c) The Author(s) 2021

\begin{abstract}
River Malaba sub-catchment tends to experience dramatic flooding events, with several socio-economic impacts to the nearby communities, such as loss of lives and destructions of physical infrastructure. Analysis of spatiotemporal extents to which settlements, crops and physical infrastructures tend to be inundated are vital for predictive planning of risk-based adaptation measures. This paper presents a case study on flood risk assessment for Ugandan River Malaba sub-catchment. We applied the two-dimensional Hydraulic Engineering Center's River Analysis System (2D HEC-RAS) for modelling of flooding extents. We considered extreme flow quantiles, lower and upper quantiles corresponding to the $95 \%$ confidence interval limits aimed at determining uncertainties in the flooding extents. Spatial extents of inundation on human settlement, land cover and infrastructure were analysed with respect to return periods of extreme flow quantiles. Finally, we estimated economic loss on infrastructure due to flooding. Results from the 2D HEC-RAS model were satisfactorily comparable with the results of observations. Amongst the land use types, cropland exhibited the highest vulnerability with at least 10,234.8 hectare (ha) susceptible to flooding event of 100-year return period (YRP). Inundated built-up land-use exhibited the highest vulnerability percentage increase (90\%) between 2- and 100-YRP. In US Dollar, about US\$33 million and US\$ 39 million losses are estimated at 2- and 100-YRP, respectively, due to inundated rice gardens and these indicate a looming high risk of household food insecurity and poverty. Several infrastructure including 15 academic institutions, 12 health facilities, 32 worshiping places remain annually vulnerable to flooding. At least $6 \mathrm{~km}$ and $7 \mathrm{~km}$ of road network are also susceptible to flooding under extreme flows of return periods 2 and 100 years, respectively. Churches exhibited the highest economic losses of US\$ 855,065 and US\$1,623,832 at 2-YRP and 100-YRP, respectively. This study findings are relevant for planning the development of sustainable flood risk adaptation pathways given the established destructions within the sub-catchment due to flooding.
\end{abstract}

Keywords Hydrodynamic modelling $\cdot$ Floods $\cdot$ River Malaba sub-catchment $\cdot$ Vulnerability $\cdot$ 2D HEC-RAS $\cdot$ Flooding impacts

\section{Abbreviations}

LQ Lower quantiles corresponding to confidence limits of $95 \%$ confidence interval

Q Extreme flow

Ambrose Mubialiwo

mambroze@gmail.com

1 Africa Center of Excellence for Water Management, Addis Ababa University, PO Box 1176, Addis Ababa, Ethiopia

2 Department of Civil and Environmental Engineering, Kyambogo University, Kyambogo, PO Box 1, Kampala, Uganda

3 Department of Water Resources and Irrigation Engineering, Arba Minch University, PO Box 21, Arba Minch, Ethiopia
UQ Upper quantiles corresponding to confidence limits of $95 \%$ confidence interval

YRP Year return period

4 School of Natural Resources, University of Nebraska-Lincoln, Lincoln, NE 68583, USA

5 Center for Agroecology, Water and Resilience (CAWR), Coventry University, Coventry, UK

6 Department of Mathematics, University of Manchester, Manchester M13 9PL, UK 


\section{Introduction}

Floods are natural disasters with the highest global occurrence and broader physical distribution producing severe damages in many countries (Najibi and Devineni 2018). The occurrence of floods could be attributed to human factors. For instance, conversation of land use types from one state to another for various purposes, such as settlement, agriculture, urbanisation, and other recreational activities especially near the river banks (Alawamy et al. 2020). This can result in extensive unexpected implications, such as alteration of the hydrological processes, hence exacerbating the occurrence of weather disasters (Apollonio et al. 2016; Kilama Luwa et al. 2020; Szwagrzyk et al. 2018; Zope et al. 2016). In addition, climate variability could be regarded as one key cause of the disasters. The most updated climate projections indicate that floods in several parts of the world will likely increase in intensity and frequency in the future (Hirabayashi et al. 2021).

Several flooding events (Table 6 of Appendix A) have impacted Uganda. These events result in considerable socioeconomic impacts including damage of crops, destruction of infrastructures including roads, bridges, schools, and loss of livestock and human lives. River Malaba sub-catchment is an example of the floodplains which have suffered dramatic floods, especially in its low-lying areas (Mayega et al. 2015; Ministry of Water and Environment 2018). The nearly flat topography facilitates the emplacement of houses or infrastructures. However, human lives and their property are at high risk of inundation. In River Malaba sub-catchment and the neighbouring areas, rainfall shows an increasing trend and multi-decadal variability (Mubialiwo et al. 2020; Onyutha et al. 2020). Furthermore, the study by Onyutha et al. (2021a) reported a likely general increase in precipitation in the 2050s, 2070s and 2090s over the entire Uganda, where the study area is located. The positive trends in rainfall have resulted in more recurrent floods over the period 2010-2019 than from 1960 to 2009 (Onyutha et al. 2020). However, the positive trends in rainfall may be affected by rising temperatures due to likely increase in evapotranspiration (Xu et al. 2017). Besides, flooding events may increase at a slower rate than rainfall which is an indication of climate change impact (Bucchignani et al. 2018; Padulano et al. 2021). The sub-catchment hydrological regimes have also been greatly influenced by land use changes (Jiang et al. 2014). The possibility of experiencing more floods of varying magnitudes in future in the study area presents a worrying situation for water resources management. To effectively manage the associated impacts of flooding, there is need for predictive planning and operation of climate change adaptation measures (Xu et al. 2017). Such planning can be supported by provision of comprehensive information or maps of flood inundation and extents of infrastructure and property that can be affected by flooding as well as vulnerability of the local population. In addition, to reduce the effects of natural disasters, there is need to evaluate their socio-economic impacts and to consider management strategies (structural and non-structural).

Flood inundation mapping can be achieved by mimicking the physics of floodwaters in the river systems through hydrodynamic modelling using a number of numerical tools. Numerical (hydrodynamic) models can be categorised as one-dimensional (1D), two-dimensional (2D) or threedimensional (3D) (Teng et al. 2017). 1D models consider one directional flow along the centreline of the river channel and are suitable when detailed analysis is not essential (Alkema 2007). 2D models make it possible to evaluate the landscape effect on the magnitude of flooding especially in near-flat topography (Alkema 2007), such as the present study area. 3D models are rarely used, since 2D shallow water approximations are considered adequate especially in areas with limited high resolution data, such as the current study area (Teng et al. 2017). 2D models have exhibited commendable performance. For instance, the study by Dhungel et al. (2019) revealed superior performance of 2D model in simulating flow depth and velocity in the lower Provo river, USA. Ghimire (2019) established that with fine resolution survey data and availability of local data, 2D models can present sound performance.

There are various 2D hydrodynamic models, such as the Hydraulic Engineering Center's River Analysis System (2D HEC-RAS) (Brunner 2016), SOBEK Suite DELFT3D (Deltares systems 2019), MIKE 21 (DHI 2017), TUFLOW HPC (Heavily Parallelised Compute) (BMT-WBM 2018). Whereas most hydrodynamic models are commercial, 2D HEC-RAS is freely available for use. HEC-RAS is a popular modelling program that computes water surface profiles in natural rivers and other channels applicable in floodplain management.

Recently, 2D HEC-RAS model has attracted extensive applications in flood risk assessment. For instance, Pinos and Timbe (2019) compared the performance of four twodimensional hydraulic models 2D HEC-RAS included, in regard to estimation of flood inundation maps. The study revealed reliable performance of 2D HEC-RAS (Pinos and Timbe 2019). Ongdas et al. (2020) presented commendable performance of 2D HEC-RAS when applied for flood hazard maps generation for Yesil (Ishim) river in Kazakhstan. Other studies that applied 2D HEC-RAS include (Garcia et al. 2020; Kumar et al. 2019; Rangari et al. 2019).

2D models have been identified to provide suitable information to policymakers as they can clearly indicate which areas are to be inundated faster to make proper evacuation and/or resettlement plans (Alkema 2007). To the best of the authors' knowledge, by the time of conducting the present 


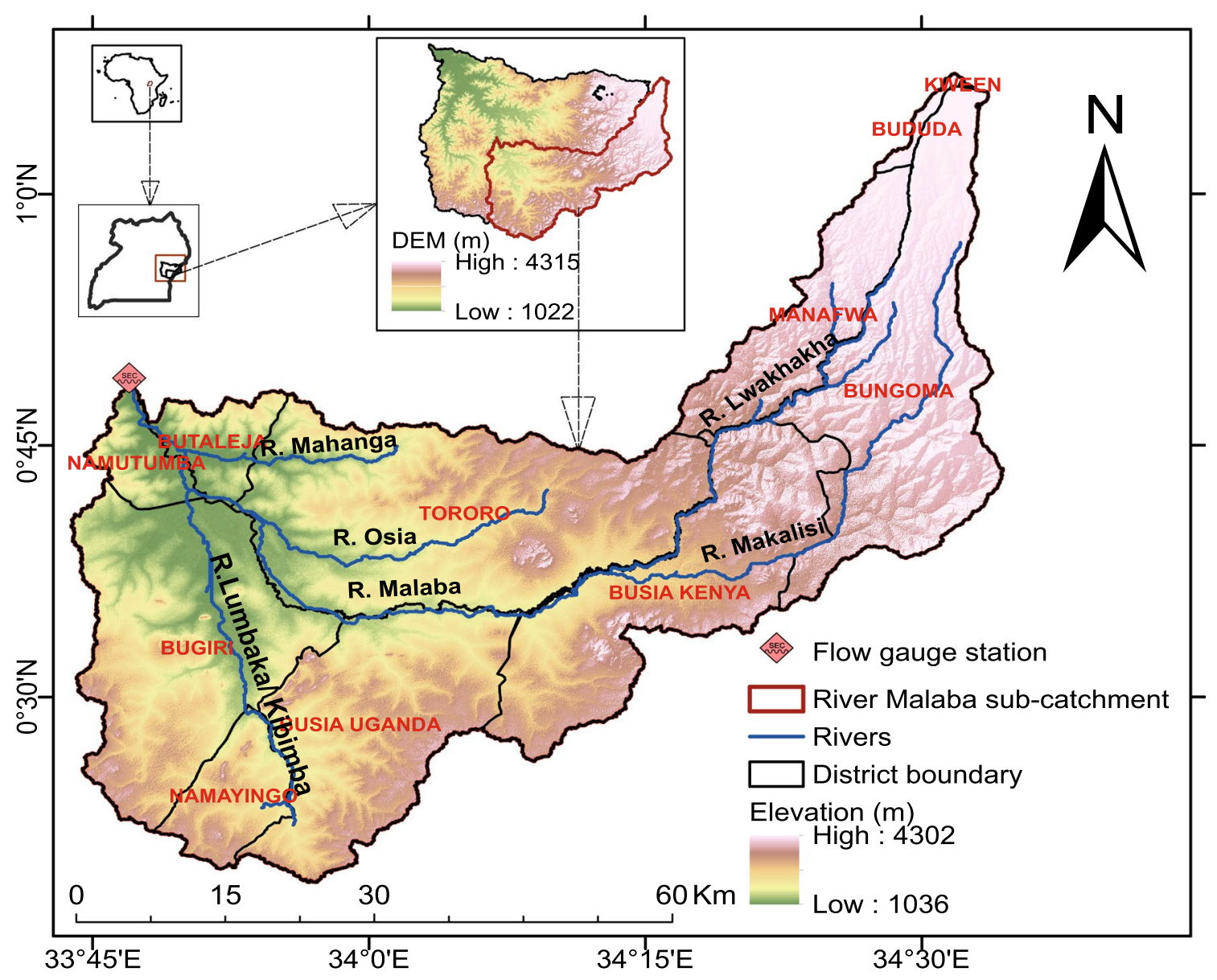

Fig. 1 Study area showing the elevations, river system and hydrological station. The background map is the digital elevation model (DEM) obtained from https://asf.alaska.edu/data-sets/sar-data-sets/alos-palsar/. (Accessed: 10 June, 2021)

study, there were no previous studies that performed hydrodynamic modelling of floods in the study area which could contribute to establishment of sustainable risk-based water resources management strategies. Therefore, the present study applied the 2D HEC-RAS hydrodynamic model for the purpose of identifying the inundation extents across the study area during flooding events of varying return periods. The study further assessed the socio-economic impact of floods on the society.

\section{Materials and Methods}

\subsection{The Study Area}

River Malaba sub-catchment (Fig. 1) is transboundary with a total drainage area of about $3500 \mathrm{~km}^{2}$, shared between Uganda (approximately $69 \%$ or $2395 \mathrm{~km}^{2}$ ) and Kenya (around $31 \%$ or $1100 \mathrm{~km}^{2}$ ). The sub-catchment stretches between latitudes $0^{\circ} 19^{\prime} \mathrm{N}$ and $1^{\circ} 07^{\prime} \mathrm{N}$ and longitudes $33^{\circ}$ $37^{\prime} \mathrm{E}$ and $34^{\circ} 37^{\prime} \mathrm{E}$. It comprises of River Malaba formed by two tributaries of Lwakhakha and Makalisi and later joined by Lumbaka/Kibimba, Osia and Mahanga tributaries. The sub-catchment is part of the Mpologoma catchment within Kyoga Water Management Zone (KWMZ). River Malaba originates from Mount Elgon at about $4315 \mathrm{~m}$ above sea level criss-crossing through districts of Bududa, Manafwa, Tororo, Butaleja reaching the shores of Lake Kyoga on the western side at about $1055 \mathrm{~m}$ above sea level, where it discharges into Mpologoma River.

Because of the steep topographic gradient between the highlands of Mount Elgon and the lowlands, the upstream areas of Manafwa and Bududa experience landslides, while the downstream regions suffer from floods (Mayega et al. 2015; Ministry of Water and Environment 2018). The subcatchment main land use is rain-fed subsistence agriculture engaging almost $85 \%$ of the population. While dense forests are found in the highlands of Mount Elgon, the remaining areas comprise of agricultural and grassland, fallow land, and isolated woodlots. Petric Plinthosols and Gleysols form the major soils types in the sub-catchment but with other 
categories including Lixic ferrasols, Acric ferrasls and Nitisols (Barasa et al. 2017; Kitutu et al. 2009).

At the national level, Uganda's climate is mostly influenced by the Monsoons and Inter-Tropical Convergence Zone (ITCZ). This results in a bimodal rainfall distribution as they move from the North to South and viceversa (Ministry of Water and Environment 2014). However, locally, the climate of the present study area is somewhat influenced by the presence of large water bodies (such as Lake Victoria and Kyoga) and the Mount Elgon slope breezes with a tendency of disturbing the afternoon convection (Camberlin 2009). The average annual rainfall in the area reaches $1375 \mathrm{~mm}$, but Bududa and Manafwa districts experience slightly much more rains (of up to $1800 \mathrm{~mm}$ ). The March to May and June to October happen to be the wettest and driest seasons, respectively, with an average temperature range of 15.8-30.6 ${ }^{\circ} \mathrm{C}$ (Barasa et al. 2013).

\subsection{Research Data}

In this study, both primary and secondary data sets were considered as detailed below. Primary data included the river geometry and socio-economic information. Secondary data comprised hydrometric, physiographic, physical infrastructure. Other secondary information included the household size which was adopted from the previous study (Mubialiwo et al. 2021a).

\subsubsection{Digital Elevation Model and River Geometry}

The digital terrain model (DEM) of the study area with a resolution of $12.5 \mathrm{~m}$ was obtained from the ALOS PALSAR database, managed by the Alaska Satellite Facility (via https://asf.alaska.edu/data-sets/sar-data-sets/alos-palsar/; Alaska Satellite Facility 2021) (accessed: 10 June, 2021). The river geometry including cross sections with an interval of $500 \mathrm{~m}$ were obtained using the Engineer's Geographic Positioning System Real-Time Kinematic (GPS-RTK). The floodplain extents of the October 2007 and March 2010 events at various locations were obtained by established the flood marks (mainly flood depth) following well-documented approaches (Koenig et al. 2016). This information was used to validate the flood inundation polygons. Furthermore, information about structures along the river such as bridges within the floodplains was obtained. In this study (especially in low-lying flood prone areas), most of the bridges were simple structures. Based on this, culverts were applied as an estimate, representing the simple bridge openings.

\subsubsection{Land Use Map}

Land use land cover (LULC) maps with a resolution of $30 \mathrm{~m}$ for three different years (2010, 2015 and 2017) (Fig. 2a-c) were obtained from the National Forest Authority (NFA) of Uganda. The obtained maps were already classified by NFA by unsupervised classification. This approach has recently been recommended by Ma et al. (2020) due to the lower field data sample requirements as compared to the supervised method. In the present study, LULC changes over the study area from 2010 to 2017 were quantified prior to hydrodynamic modelling (Fig. 3). Bare land, built-up areas and cropland increased from 2010 to 2017, while water surface decreased (Fig. 3). A decrease in water surface is an indication of reduced available water. Despite a decrease in forestland from 2010 and 2015, a slight increase occurred from 2015 to 2017. Forestland exhibited the highest decrease from 2010 to 2015, while crop land had the highest increase from 2010 to 2017. Grassland increased from 2010 to 2015 and later decreased.

\subsubsection{Flow Data and Processing}

Simulated daily rainfall-runoff was adopted from the earlier study (Mubialiwo et al. 2021b). The series covered the period 1999-2016 totalling to 18 years. Daily rainfall-runoff was simulated using seven lumped conceptual rainfall-runoff models (Table 7 of Appendix B). Evaluation of the mismatches between observed and simulated flows were based on a total of nine "goodness-of-fit" metrics (Mubialiwo et al. 2021b). Rainfall-runoff discharge was adopted instead of observed river flow to capture the dynamics of modifying land use types and their corresponding effect on hydrology. Besides, observed river flow cannot reflect the amount of flow in the floodplain as it is only measured at one location. It is vital to differentiate between rainfall-runoff discharge and river flow. Rainfall-runoff discharge refers to the inflowing discharge into the river, and was considered (in a lumped way) upstream of a given location along the river; or along a given river stretch. In other words, rainfall over the catchment generates runoff which flows into the river. The amount of runoff depends on the intensity of the rainfall. In turn, the magnitude of flooding event depends on the amount of runoff generated. The river flow (at a given point) comprises the transformation of the rainfall-runoff discharges (upstream of that point, and at previous time steps), after being routed through the river network.

To guide further use of the rainfall-runoff discharge data in hydrodynamic modelling, trend statistics were computed to assess the presence of either monotonic trends or seasonal components (Table 1). Analyses adopted the same approaches previously applied by Mubialiwo et al. (2020, 2021c), and Onyutha et al. (2021b) as follows: The linear 

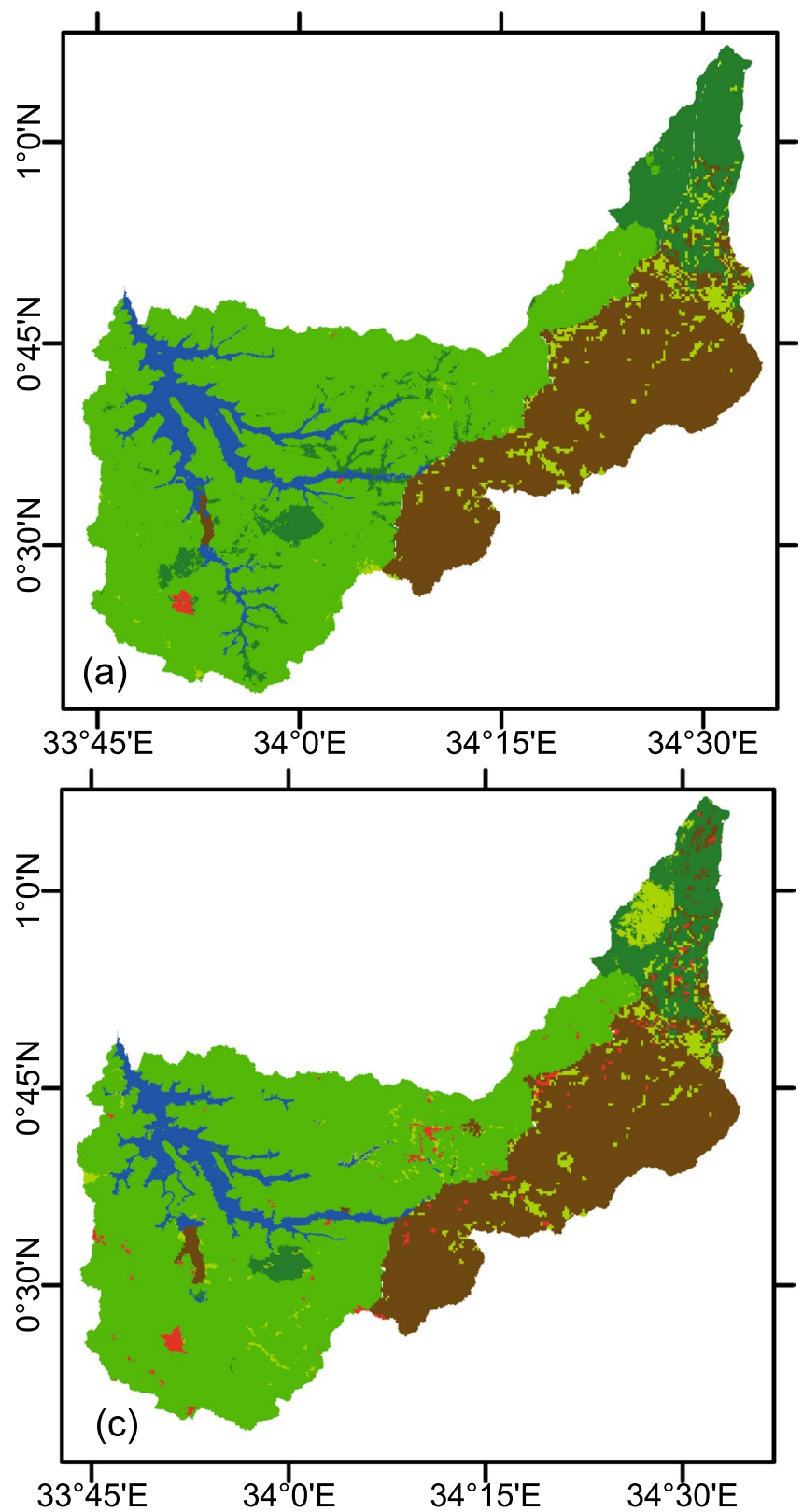

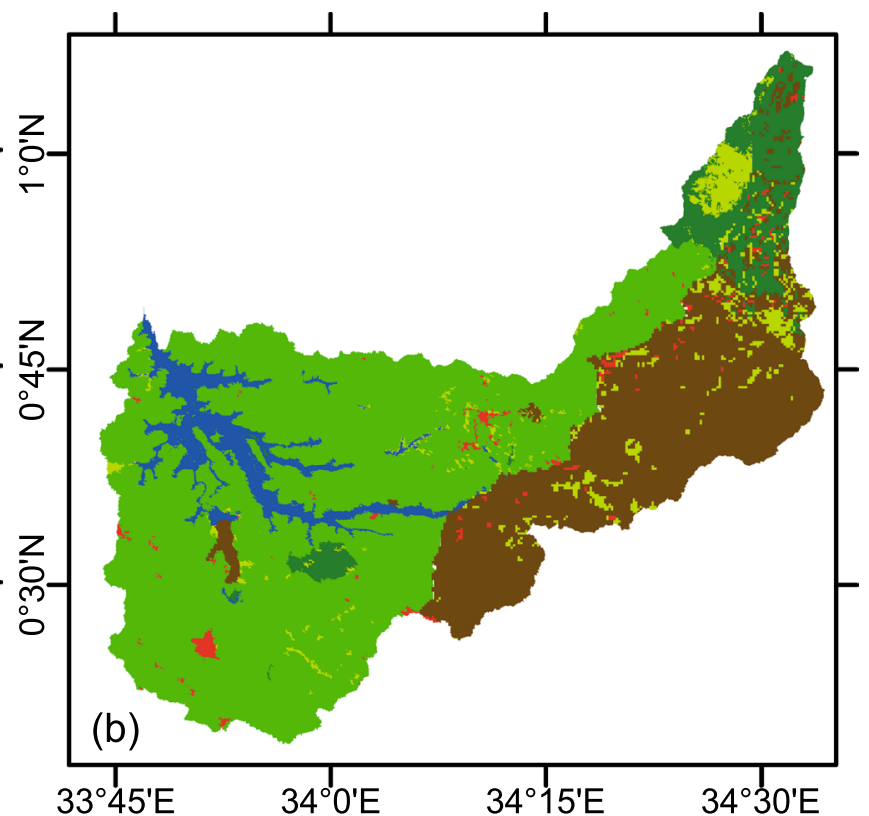

Land use classes

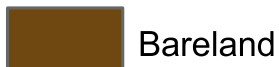

Built-up areas

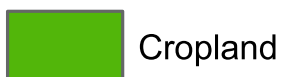

Forestland

Grassland

Water surface

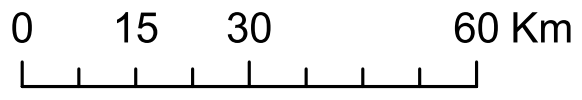

Fig. 2 a 2010, b 2015 and c 2017 land-use classification maps of the study area. The legend applies to (a-c)

trend analyses on rainfall-runoff discharge followed the approach by Sen (1968) and Theil (1950), while significance of the trend was done using the cumulative sum of the difference between exceedance and non-exceedance counts of data (Onyutha 2021). Details of the adopted approaches for trend analyses are provided in Appendix C.

Rainfall-runoff discharge exhibited positive trends in both seasonal and annual time scales.

Except for MAM, the JJAS, OND and annual rainfall-runoff discharges had $H_{o}$ (no trend) rejected $(Z>1.96, p<0.05)$. This could be attributed to the increasing precipitation amount and decreasing potential evapotranspiration. Significant positive sub-trends occurred from around 2007. An important step in the hydrodynamic modelling is selection of return periods for hydrographs to drive the model. From the fitted extreme value distribution (EVD) (Mubialiwo et al. 2021b), the extreme flow quantiles (return levels) at six different return periods $(2,5,10,25,50$, and 100 years) were extracted (Table 2). Apart from using the extreme flow quantiles (Q), the lower (LQ) and upper (UQ) quantiles corresponding to the $95 \%$ confidence interval limits were computed to determine uncertainties in the flooding extents (Table 2) (Ialongo 2019). Synthetic hydrographs were developed for each return period and used as 
Fig. 3 Land use changes from 2010 and 2017

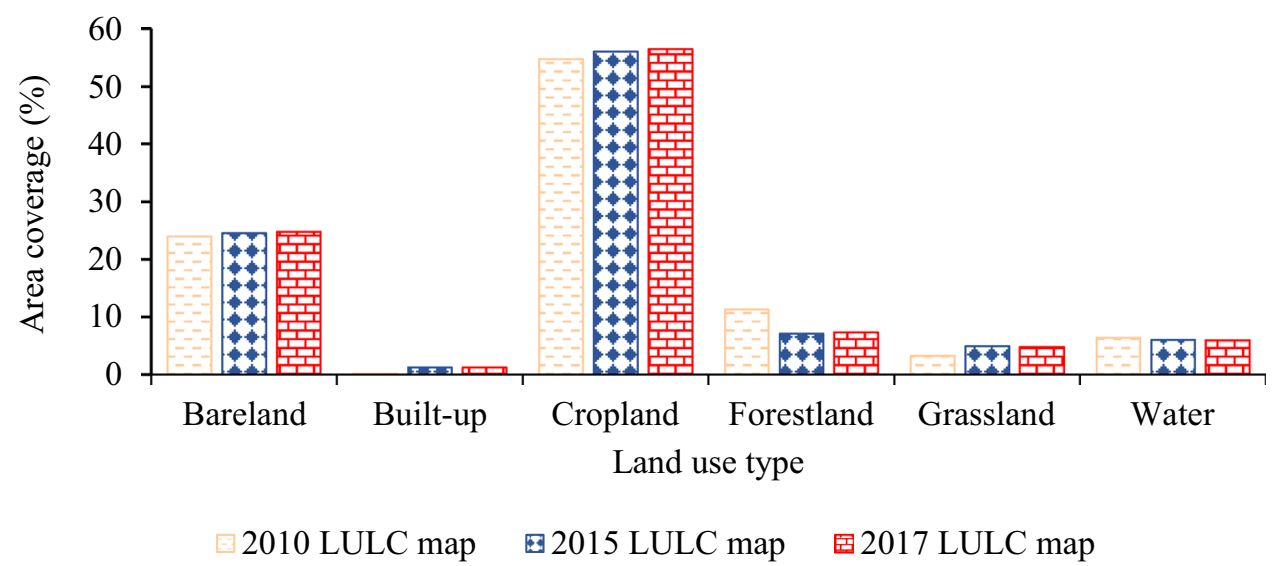

Table 1 Trend magnitude and direction in simulated rainfall-runoff discharge at annual and seasonal scales

\begin{tabular}{|c|c|c|c|c|}
\hline \multirow[t]{2}{*}{ Trend } & \multicolumn{4}{|c|}{ Time scale } \\
\hline & $\begin{array}{l}\text { March- } \\
\text { May } \\
\text { (MAM) }\end{array}$ & $\begin{array}{l}\text { June-Sep- } \\
\text { tember } \\
\text { (JJAS) }\end{array}$ & $\begin{array}{l}\text { October- } \\
\text { December } \\
\text { (OND) }\end{array}$ & Annual \\
\hline $\begin{array}{l}\text { Trend mag- } \\
\text { nitude, } \mathrm{m} \\
\left(\mathrm{m}^{3} \text { year }^{-1}\right)\end{array}$ & 31.20 & 48.36 & 62.12 & 45.37 \\
\hline $\begin{array}{l}\text { Trend direc- } \\
\text { tion, } Z \text { value }\end{array}$ & 1.88 & 2.81 & 2.69 & 2.53 \\
\hline
\end{tabular}

model input boundary conditions at the upstream of reaches (Bedient and Huber 2002; Sule and Alabi 2013).

\subsubsection{Physical Infrastructures}

Distribution of settlement clusters, and location of physical infrastructures (such as churches, schools, health facilities) were obtained from the Uganda Bureau of Statistics (Uganda Bureau of Statistics 2020, 2018) (Fig. 4).

Ground measurements were also taken using the GPSRTK to confirm the location of some infrastructure especially the airport, train station and some roads.

\subsection{Methodology}

\subsubsection{Description of the Used Model}

As stated before, the Hydrologic Engineering Center's River Analysis System (HEC-RAS) was applied in this study. The model can simulate both steady and unsteady flow components. The steady flow element has the competence of modelling the subcritical, supercritical as well as mixed flow regime, water surface profiles. On the other hand, the unsteady flow component of HEC-RAS is capable of modelling independent $1 \mathrm{D}$ or 2D unsteady flow or combined 1D and 2D unsteady flows (Brunner 2016). Herein, 2D HEC-RAS model 5.0.7 was used to simulate floods. The study involved computation of flood depth, and assessment of inundation extent on population, crops and infrastructure. The model simulated floods according to the following expressions (Brunner 2016):

$\frac{\partial H}{\partial t}+\frac{\partial p}{\partial x}+\frac{\partial q}{\partial y}=r$

$$
\begin{aligned}
\frac{\partial p}{\partial t}+ & \frac{\partial}{\partial x}\left(p^{2} h^{-1}\right)+\frac{\partial}{\partial y}\left(p q h^{-1}\right) \\
= & -n^{2} k g h^{-2}\left(p^{2}+q^{2}\right)^{0.5}-g h \frac{\partial H}{\partial x} \\
& +p k+\frac{\partial}{\rho \partial x}\left(h \lambda_{x x}\right)+\frac{\partial}{\rho \partial y}\left(h \lambda_{x y}\right)
\end{aligned}
$$

Table 2 Simulated extreme flow quantiles $\left(\mathrm{m}^{3} \mathrm{~s}^{-1}\right)$ at varying return periods and corresponding upper and lower quantiles at $95 \%$ confidence interval limits of extreme values

\begin{tabular}{lllllll}
\hline Return period (year) & \multicolumn{1}{l}{5} & \multicolumn{1}{l}{10} & 25 & 50 & 100 \\
\hline LQ $\left(\mathrm{m}^{3} \mathrm{~s}^{-1}\right)$ & 47.14 & 83.00 & 104.99 & 128.25 & 139.69 \\
Q $\left(\mathrm{m}^{3} \mathrm{~s}^{-1}\right)$ & 95.64 & 122.34 & 142.55 & 169.25 & 189.45 \\
UQ $\left(\mathrm{m}^{3} \mathrm{~s}^{-1}\right)$ & 144.14 & 161.69 & 180.10 & 210.25 & 239.21 & 209.65 \\
\hline
\end{tabular}



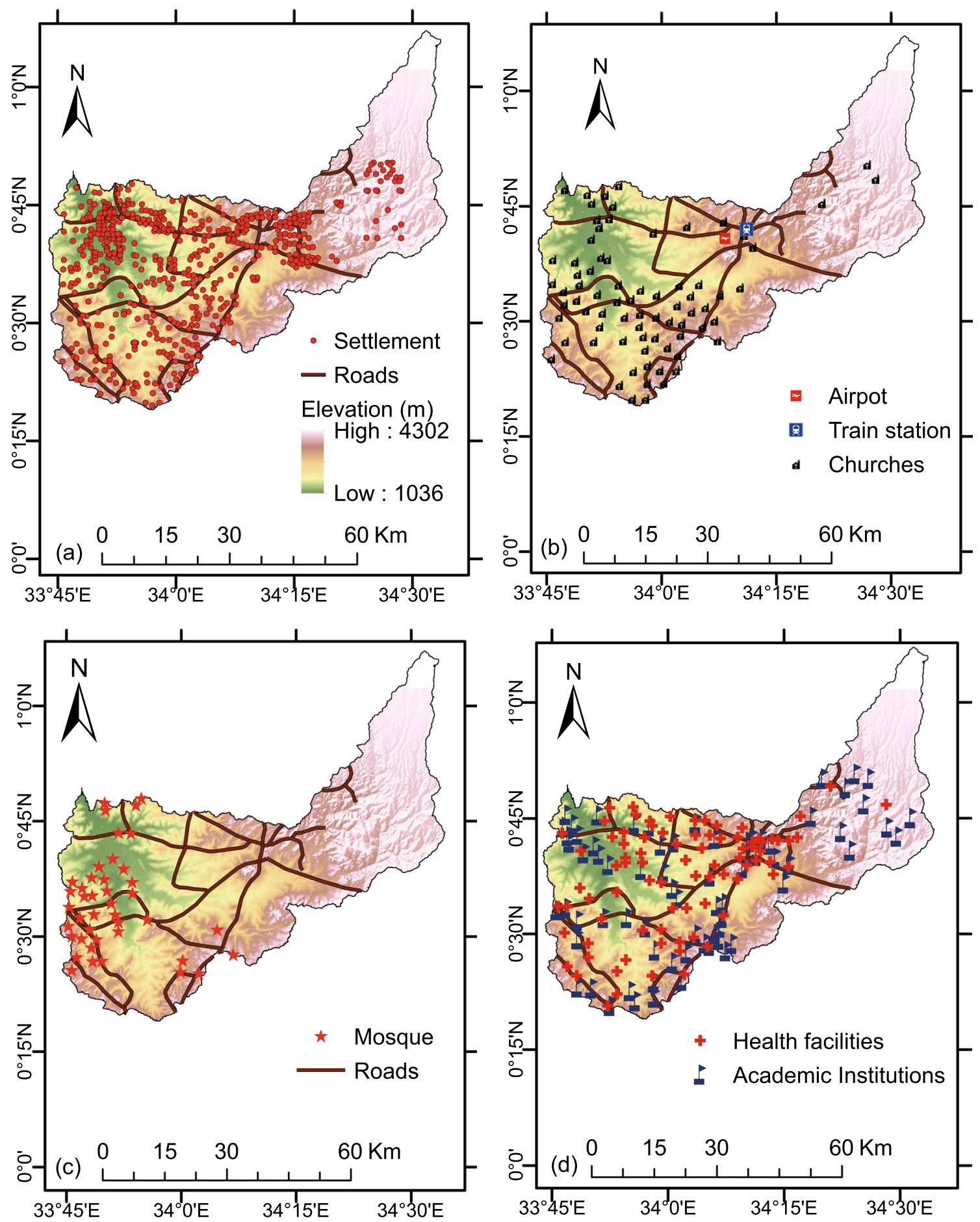

Fig. 4 Distribution of physical infrastructures including a human settlement, roads $\mathbf{b}$ airport, train station, churches, $\mathbf{c}$ mosques $\mathbf{d}$ health facilities, academic institutions. The elevation legend on (a) as well applies for (b-d)

$$
\begin{aligned}
\frac{\partial p}{\partial t}+ & \frac{\partial}{\partial x}\left(p q h^{-1}\right)+\frac{\partial}{\partial y}\left(q^{2} h^{-1}\right) \\
= & -n^{2} q g\left(p^{2}+q^{2}\right)^{0.5} h^{-2}-g h \frac{\partial H}{\partial y} \\
& +q k+\frac{\partial}{\rho \partial x}\left(h \lambda_{x y}\right)+\frac{\partial}{\rho \partial y}\left(h \lambda_{y y}\right)
\end{aligned}
$$

where $h$ is the water depth (m), $p$ and $q$ denote the specific flow in the directions of $x$ and $y$ measured in $\mathrm{m}^{2} \mathrm{~s}^{-1} \cdot r$ is the net rainfall in $\mathrm{m}$. $H$ is the surface elevation in $\mathrm{m}$, while $g$ stands for acceleration due to gravity measured in $\mathrm{ms}^{-2} . n$ is the manning's coefficient $\left(\mathrm{sm}^{-1 / 3}\right), \rho$ is the density in $\mathrm{kgm}^{-3}$. 
$\lambda_{x x}, \lambda_{x y}, \lambda_{y y}$ represent the effective shear stress components, while $k$ is the Coriolis measured in $\mathrm{s}^{-1}$. For the case when the analysis considered diffusive wave equation, then the inertial components in Eqs. (2) and (3) is left out.

HEC-RAS has the capability to analyse either a fully 2D Saint Venant equation or the 2D diffusive wave equation following an implicit finite-volume approach (Brunner 2016). Both 2D diffusive wave and Saint Venant equations can exhibit close performance (Dhungel et al. 2019; Ongdas et al. 2020; Shustikova et al. 2019). However, in the present study, the 2D diffusive wave equation was adopted, because it supports longer time steps, is faster, and produces stable and accurate solutions than the Saint Venant equations (Ongdas et al. 2020; Sarchani et al. 2020).

\subsubsection{Uncertainty Analysis and Calibration of Manning's Roughness Coefficients}

In this study, we assessed the possible uncertainties induced in the flow/flood simulation by changes in land use from 2010 to 2017. This was done by evaluating the difference between the three LULC maps with respect to Manning's roughness coefficients. First, calibration was performed on the six major land use types (Fig. 2) by applying the Manning override regions function in HEC-RAS (Brunner 2016). Subsequently, the calibrated parameters were then used to simulate the floods in HEC-RAS. Because of the small sample size $n$ of 6 , the Student's $t$ - distribution was adopted (Brereton 2015). Statistical significance was set at $p<0.05$. The analysis considered three combinations of 2010 and 2015, 2010 and 2017, and 2015 and 2017. The test statistics $t$ is computed as follows:

$t=\frac{\bar{x}_{1}-\bar{x}_{2}}{s_{\mathrm{p}} \sqrt{\frac{1}{n_{1}}+\frac{1}{n_{2}}}}$

with

$s_{\mathrm{p}}=\sqrt{\frac{\left(n_{1}-1\right) s_{1}^{2}+\left(n_{2}-1\right) s_{2}^{2}}{n_{1}+n_{2}-2}}$

where $s_{\mathrm{p}}$ is an estimator of the collective standard deviation of the two samples, $s_{1}$ and $s_{2}$ denotes the standard deviation, $\bar{x}_{1}$ and $\bar{x}_{2}$ are the mean values, $n_{1}$ and $n_{2}$ are the sample size of the manning's roughness coefficients from say 2010 and 2015, respectively. The $p$ value can be computed using Ms Excel function TDIST (value, $d f$, tail). Considering the period of flow data (1999-2016), the 2015 LULC map (Fig. 2b) was adopted in defining the manning's coefficient in the HEC-RAS model.

\subsubsection{Hydrodynamic Modelling of Floods}

Modelling was done using the inputs as DEM, 2015 land cover map (for manning's coefficients), and synthetic hydrographs for different return periods (see Sects. 2.2.1 to 2.2.3 for details). The 2D flow area covered the low-lying region which is prone to flooding (Fig. 5). Two different boundary conditions (hydrograph and normal depth) were defined. Composite hydrograph boundary conditions were defined upstream of every reach representing the runoff discharges. The normal depth boundary conditions were defined at the downstream of the river and at the edges of the model, where the runoff is presumed to flow. 2D HEC-RAS calculated the outflow, flood depth, water surface elevation, and velocity for each grid as the flood-water propagated throughout the domain to the normal boundary conditions.

The 2D computational mesh was set up with a cell size of $12.5 \times 12.5 \mathrm{~m}$. This selection of grid was to ensure minimal or no deviation from the DEM resolution $(12.5 \times 12.5 \mathrm{~m})$. Selection of particular time steps in HEC-RAS may influence the results. Small time steps can result in very long computation times, while too large time steps may as well cause numerical diffusion hence model instability (Brunner 2016). In the present study, stability of the model was ensured by estimating the time step based on the Courant-Friedrichs-Lewy approach as follows (Brunner 2016):

$C=\frac{V \Delta t}{\Delta x}=\leq 1$

where $C$ stands for the Courant number (dimensionless), $V$ is the flood wave velocity $\left(\mathrm{ms}^{-1}\right), \Delta t$ is the computational time step (s), $\Delta x$ denotes the grid size $(12.5 \mathrm{~m})$.

Evaluation of model results is an essential component to measure performance. Evaluation of the 2D HEC-RAS model necessitated historical record of flood events. This could be in form of delineated extent from observations or remote sensing images. Unfortunately, it is worth noting that there are no official historical records of observed flood events extents for the current study area despite the recurrent disasters. Even the available satellite images do not clearly capture the entire present study area. Nevertheless, the flood image for the 20 October 2007 flood by Red cross was used (accessed: 11 July, 2021). This event affected almost the entire Uganda (Reliefweb 2007). Prior to its use in model evaluation, the flood image (map) was corrected with guidance of the flood marks information obtained as per Sect. 2.2.1. The image was also compared with another one by Reliefweb (2020) (accessed: 11 July, 2021). Model performance was assessed based on several metrics including False Alarm Ratio (FAR), Hit Rate (HR), Critical Success Index (CSI) and Bias Error $\left(B_{\mathrm{e}}\right)$ as shown in Eqn. (7) to (10) (Sampson et al. 2015). These performance criteria have been applied in recent studies (Costabile et al. 2020; Ongdas 


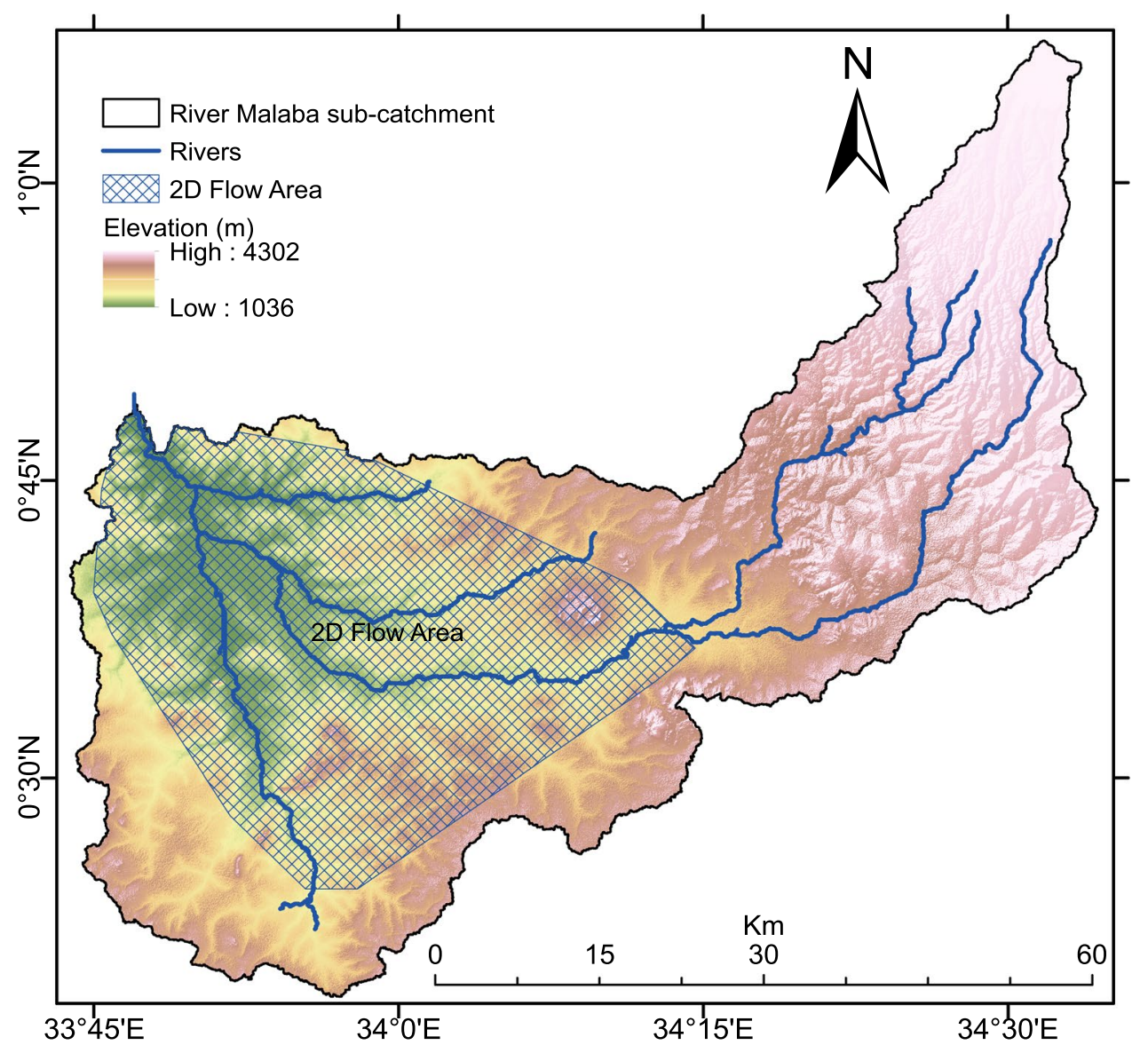

Fig. 5 2D HEC-RAS flow area

et al. 2020; Sampson et al. 2015). Consider $A_{\text {sim }}, A_{\text {obs }}$ as the simulated and observed flooded areas, respectively. Assume $A_{\text {cor }}, A_{\text {over }}, A_{\text {under }}$ denote the correctly, over- and under-predicted flood areas, respectively, all measured in $\mathrm{km}^{2}$ :

$\mathrm{FAR}=\frac{\left(A_{\mathrm{sim}} / A_{\mathrm{obs}}\right)}{\left(A_{\mathrm{cor}}+\frac{A_{\mathrm{sim}}}{A_{\mathrm{obs}}}\right)}$

$\mathrm{HR}=\frac{\left(A_{\text {cor }}\right)}{A_{\text {obs }}}$

$\mathrm{CSI}=\frac{\left(A_{\text {cor }}\right)}{\left(A_{\text {cor }}+A_{\text {over }}+A_{\text {under }}\right)}$

$B_{\mathrm{e}}=\frac{\left(A_{\text {sim }} / A_{\text {obs }}\right)}{\left(A_{\text {obs }} / A_{\text {sim }}\right)}$

FAR is a measure of model overprediction and it varies between 0 and 1 . A value of 1 implies "all false alarm", while 0 denotes "no false alarm". HR shows how well a model mimics the benchmark inundation without necessarily chastising for overprediction. HR ranges between 0 and 1 , with 1 indicating that all wet areas in the benchmark inundation map are as well wet in the simulated output. CSI gives the combined effect of FAR and HR catering for both overprediction and underprediction. A value of 1 means perfect match between simulated and benchmark, while 0 indicates no match between the two. Finally, $B_{\mathrm{e}}$ has two ranges (0-1 and $1-\infty)$. The range of $0-1$ indicates underprediction of the model, and $1-\infty$ shows propensity of a model to overpredict (Sampson et al. 2015).

\subsubsection{Flood Damage Estimation}

Determination of economic losses due to flooding necessitated the flood depth and flood depth-damage functions for each infrastructure. The flood depths for individual infrastructure (churches, mosques, academic institutions and health facilities) spatially distributed within the inundated area were obtained from the generated flood depth map for each return period. We estimated the flood economic 
Table 3 Calibrated Manning's roughness coefficients for each land use type

\begin{tabular}{llllllll}
\hline Land use type & & Cropland & Bareland & Forestland & Water & Grassland & Built-up areas \\
\hline Calibrated Manning's roughness coefficient & 2010 & 0.039 & 0.035 & 0.170 & 0.370 & 0.035 & 0.070 \\
& 2015 & 0.410 & 0.034 & 0.150 & 0.350 & 0.400 & 0.660 \\
& 2017 & 0.450 & 0.031 & 0.155 & 0.310 & 0.380 & 0.630 \\
\hline
\end{tabular}

damage values for the extreme flow (Q) conditions. There are no site-specific damage functions for the present study area neither for the neighbouring areas. Therefore, depthdamage functions from other areas of similar topographical representation were applied to estimate the economic damage value for each of the selected infrastructure. The depth-damage function were adopted from (Chen 2007; Pinos et al. 2020; Scorzini and Frank 2017). These were applied in conjunction with the flood damage functions and damage values provided by Huizinga et al. (2017) at national level. The depth-functions for a particular infrastructure at each depth location (e.g., church 1, church 2) were obtained by interpolating from the known depth-functions. The applied depth-damage functions for each infrastructure at different return period can be found in Table 8 of Appendix D. Finally, the composite economic losses for each type of infrastructure were obtained as a summation of individual losses for the respective return periods. It is worth noting that these were mainly estimates and not the true ground economic loss values. Several studies (Amadio et al. 2019; Martínez-Gomariz et al. 2020; McGrath et al. 2019; Molinari et al. 2020; Romali and Yusop 2021; Scorzini and Frank 2017; Zarekarizi et al. 2020) have embraced the use of flood depth-damage functions in different areas across the word.

\section{Results and Discussion}

\subsection{Uncertainty Analysis and Calibration of Manning's Roughness Coefficients}

The land use types and their calibrated manning's roughness coefficients are shown in Table 3. Calibration was intended to improve the HEC-RAS model performance.

The $p$ values of $0.061,0.064$ and 0.379 for the combinations of 2010 and 2015, 2010 and 2017, and 2015 and 2017 , respectively, were greater than $\alpha(0.05)$ implying that $H_{o}$ was not rejected. This implies that changes in LULC from 2010 to 2017 was insignificant. Therefore, the river flow variation and or damage from floods within River Malaba sub-catchment could be attributed to other factors beyond LULC changes, such as climate variability. Previous study by Onyutha et al. (2021d) revealed that changes in LULC contributed only $8 \%$ to the River Mpanga flow variation. This contribution was smaller compared to other factors, such as climate variability (70\%) (Onyutha et al. 2021d). Furthermore, uncertainties in flood inundation simulations may result from the adopted manning's roughens coefficient values. In most cases, uniform instead of spatially varying values of roughness coefficient are assumed which could be a source of uncertainties (Huang and Qin 2014). However, characteristic of flooding (extent and depth) may possess a low sensitivity to changes in manning's roughness coefficient (Höffken et al. 2020).

\subsection{Model Performance in Mimicking the Historical Flood Event}

The performance of the HEC-RAS model in capturing the historical flood image are presented in Table 4 . The value of CSI indicates that the simulated flooded areas generally concur with the observed data. The value of $H R$ above 0.5 and close to 1 further confirms an acceptable fit of wet areas in both simulated and observed data set. However, values of $B_{e}$ above 1 indicate an overestimation of the model.

\subsection{Spatial Inundation Extent Analyses}

Vulnerability analyses were done to identify the extent of flooding on settlement, land cover, roads and other infrastructures. Figure 6 shows the inundation extent of settlements considering the LQ, Q and UQ for varying return periods. Flooding was highly noticeable in the low-lying areas. The spatial comparison established that inundation extent of settlements in the study area varies significantly. Settlement clusters are much concentrated in the lowest part of the flood-prone area. This could be attributed to the societal stalemates such as less onerous way of setting up buildings with always profitable investments. This statement conforms with the findings by Kiyengo et al. (2019). The study focused on establishing the spatio-temporal distribution of flash floods and evaluate why people preferred

Table 4 Model performance for flood simulation

\begin{tabular}{|c|c|c|c|}
\hline \multicolumn{4}{|c|}{ Performance metrics } \\
\hline $\begin{array}{l}\text { False alarm ratio } \\
\text { (FAR) }\end{array}$ & Hit rate $(\mathrm{HR})$ & $\begin{array}{l}\text { Critical success } \\
\text { index (CSI) }\end{array}$ & Bias error $\left(B_{\mathrm{e}}\right)$ \\
\hline 0.65 & 0.71 & 0.62 & 1.6 \\
\hline
\end{tabular}



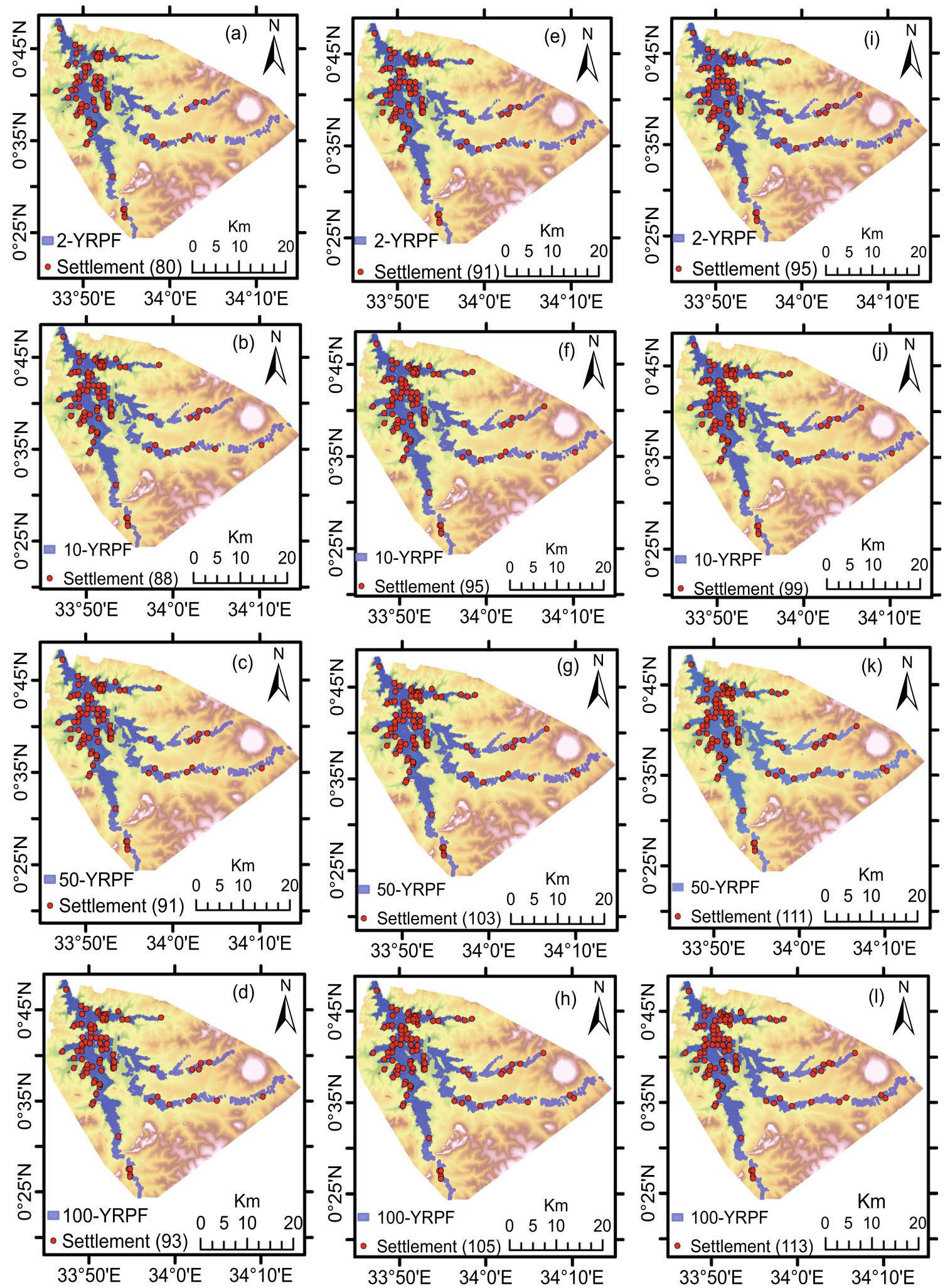

Fig. 6 Inundation extent of human settlement based on $\mathbf{a}-\mathbf{d}$ LQ, $\mathbf{e}-\mathbf{h}$ $\mathrm{Q}$ and $\mathbf{i}-\mathbf{l} \mathrm{HQ}$, at (a, e, i) 2-YRP, (b, f, j) 10-YRP, (c, g, k) 50-YRP and (d, h, l) 100-YRP. "LQ, Q and UQ" are defined in Sect. 2.2.3. "YRPF" denotes "year return period flood" The number of settle- ments in the brackets represent number of settlement clusters with each cluster having an average 10 households (Mubialiwo et al. 2021a) 
Fig. 7 Estimated populations exposed to floods computed for 2-100-year return periods. LQ, Q and UQ are defined in Sect. 2.2.3

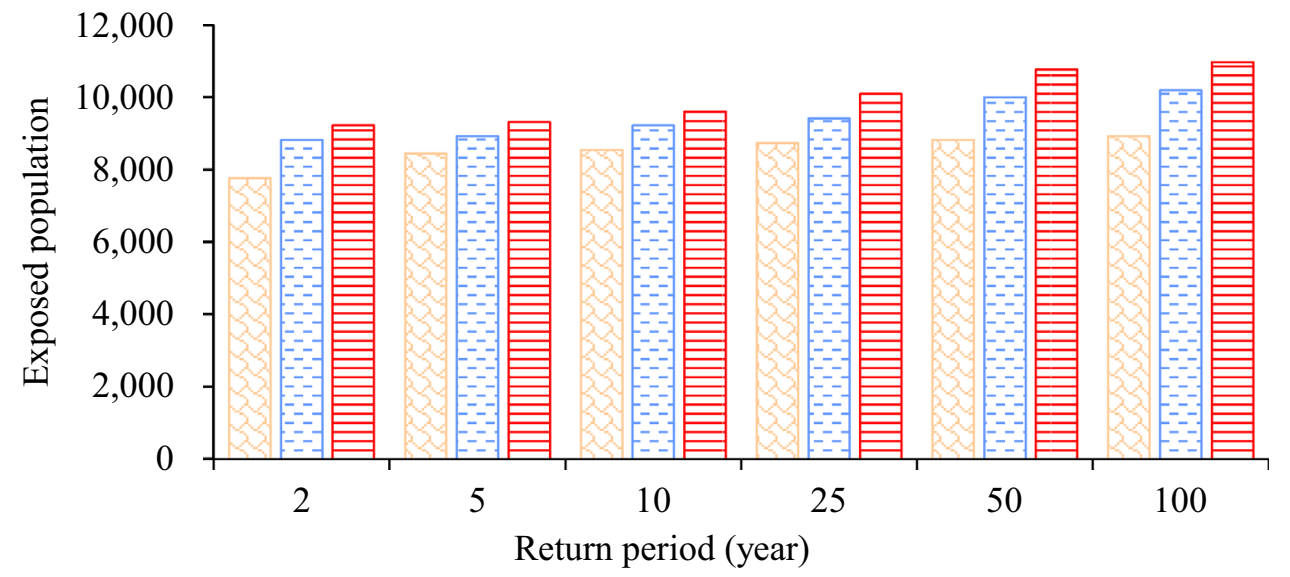

$\mathrm{LQ} \boxminus \mathrm{Q} \boxminus \mathrm{UQ}$ settling in flood-prone area in Lubiji micro-catchment, a Kampala suburb (Kiyengo et al. 2019). The escalating settlements in flood-prone areas by low-income communities worsens their vulnerability and habits. The poor land use management further contributes to increasing floods in such areas (Ramiaramanana and Teller 2021).

It is noticeable that the difference between results of 50and 100-year return periods in terms of the spatial coverage of flooded area was small even though it was expected to be large. This can be explained in three ways. First, the difference between quantiles of two return periods depends on the scale parameter (or the slope of the weighted linear regression line in quantile-quantile plot) especially for normal tailed EVD (Beirlant et al. 1996; Onyutha and Willems 2015; Willems et al. 2007). A large-scale parameter indicates high extreme flow variations (Onyutha and Willems 2015). The second explanation of the small difference between 50- and 100-year quantiles is due to the uncertainty in the statistical estimation of quantiles. In extreme value analysis, uncertainty in estimated flow quantiles increases as the considered return period goes higher than the length of the observed data series (Onyutha and Willems 2013). In this line, extrapolation of quantiles is recommended to be limited for return periods not exceeding two or three times the length of the observed data (Kangieser and Blackadar 1994). If, say, a series longer than 50 years was used, the 100 -year return level could have probably been larger than the one used in this study. Third, the topography/bathymetry which can influence LULC of the study area cannot change very much in these few years, unless the region as suffered a natural disaster. This justified by the insignificant LULC changes from 2000 to 2014 over two catchments within Uganda (Onyutha et al. 2021c, d). Thus, although the 100year return period was considered for relevance, corresponding results should be cautiously interpreted given the uncertainty involved in the estimation of the extreme quantiles.
Field activities revealed that on average, a settlement cluster had 10 households, with an average household size of 9.7 people in the present study area (Mubialiwo et al. 2021a). These values were adopted in estimating the population exposed to floods (Fig. 7). It should be noted that this number excludes those affected by landslides in the highland areas of Bududa and Manafwa districts. At 2-year return period, at least 7760 people are exposed to floods considering the lower limit of extreme flow at $95 \%$ confidence interval. The exposed population would increase by $12 \%$ and $16 \%$ for extreme and upper limit of extreme flow at $95 \%$ confidence interval, respectively, considering the 2-year return period (Fig. 7). To avert future loss of lives, authorities could make arrangement for relocation of population from risky to safer places.

There was an increase of about $13.0 \%, 13.3 \%$ and $15.9 \%$ for LQ, Q and UQ, respectively, of the exposed population from 2- to 100-year return period (Fig. 7). The government through ministry of relief, disaster preparedness and refugees has always resettled people from high risk areas in the gazetted refuge settlements (Reliefweb 2019). However, the population relocated to safe places usually returns to flood-prone areas. The key underlying reasons could include (1) population pressure in refugee camps, (2) inappropriate information on disaster preparedness, (3) cultural beliefs influencing people's ability to cope with the new environment, (4) poor service delivery in the camps, and (5) infertile land in refugee settlements (Osuret et al. 2016). Successful resettlement necessitates sensitisation of the community about its rationale as a way of building trust in the government (Neema et al. 2018).

Figure 8 shows the variation of flooding depth across the study area simulated for different return periods (2-100 years). The maximum depth varied from 3.79 to $4.53 \mathrm{~m}$ at LQ for 2-year return period and 4.62 to $5.36 \mathrm{~m}$ at UQ for 100-year return period. As earlier observed with 

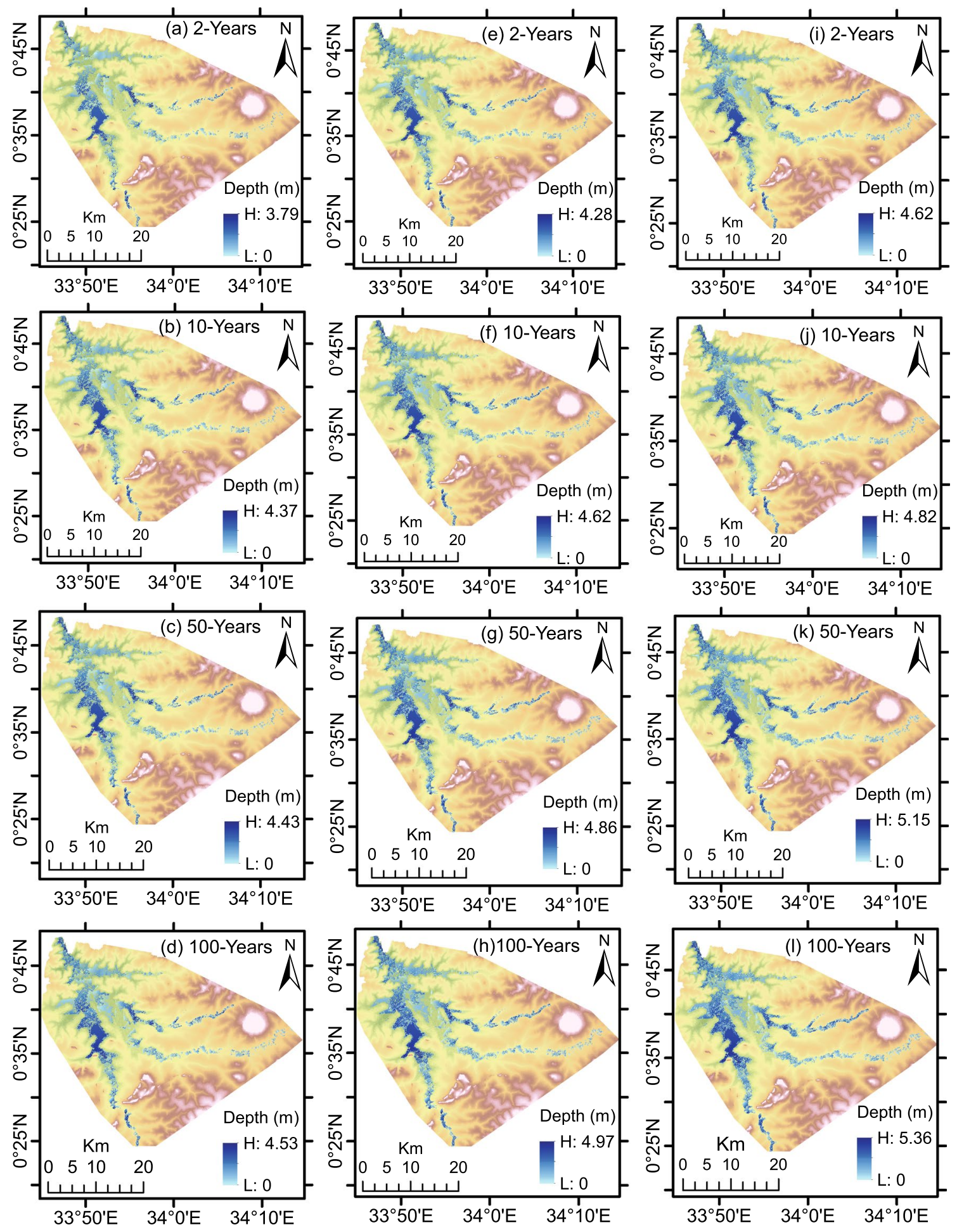

Fig. 8 Flooding depth based on a-d LQ, e-h Q and i-l HQ, at (a, e, i) 2-YRP, (b, f, j) 10-YRP, (c, g, k) 50-YRP and (d, h, l) 100-YRP. "LQ, Q and UQ" are defined in Sect. 2.2.3. "YRP" denotes "year return period". "L" and "H" denote high and low depth, respectively

flooding extent, the difference between the 50- and 100-year return periods results in terms of flood depth is small despite it being expected to be large. The same reasons according to Beirlant et al. (1996), Onyutha and Willems (2015), Willems et al. (2007) and Onyutha and Willems,(2013) still apply for this situation. The section with deepest flood water levels is observed approximately $1.6 \mathrm{~km}$ downstream of where bypass of Bugiri-Tororo road crosses Lumbaka/Kibimba tributary. 
Fig. 9 Flooding extent on different land cover types in the sub-catchment considering various return periods based on extreme flows

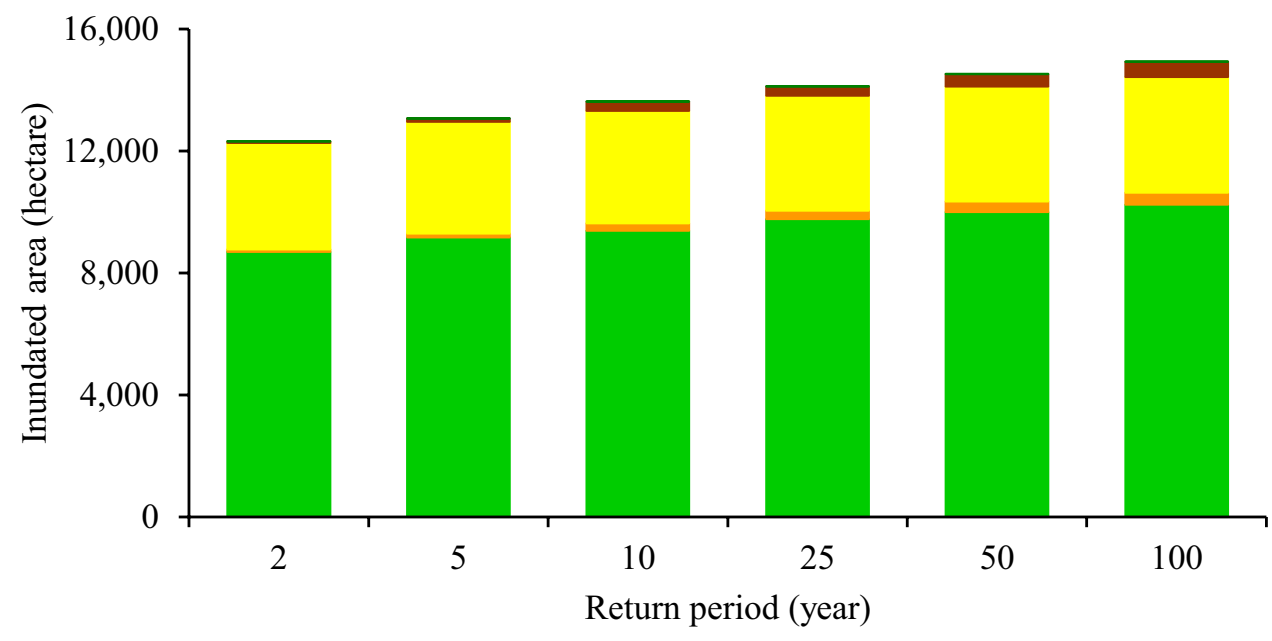

- Cropland Grassland Bareland $\square$ Builtup $\square$ Forestland
The flooding extent on various land cover types is shown in Fig. 9 for the extreme flows. Results on inundation of land cover types under LQ and UQ can be found in Fig. 13 of Appendix E. Flood vulnerability analyses results conform with the October to November 2020 field survey (Mubialiwo et al. 2021a) indicating highest percentage of vulnerability in the low-lying areas. The highest vulnerability percentage occurred in the cropland (cultivated land) with 10,234.8 hectare (ha) flooded by 100-YRP, followed by 3793.9 ha of bare land. Inundation of cropland increased by $15 \%$ from 8685 ha at 2 years to 10,235 ha at 100 years. Despite the relatively small areas of inundated built-up, these places have high population density of around 9.7 people per household (Mubialiwo et al. 2021a) mainly staying along the river banks. Besides, the inundated built-up land-use type exhibited the highest vulnerability percentage increase (90\%) between 2- and 100-YRP followed by grassland (80\%) (Fig. 9). Therefore, in the low-lying areas, effective land-use conservation and management should be emphasised.

For the inundated cropland, field survey analyses done in October to November 2020 revealed that rice is the most cultivated crop taking approximately $40 \%$, followed by maize (20\%), millet/sorghum (15\%). The other crops grown include beans, ground nuts, sweet potatoes, cassava sharing the remaining percentage. In the present study, rice which mainly doubles as both food and cash crop has been taken as an example to quantity the would-be loss if the land is inundated. Focus group discussions conducted with Namunasa stream rice farmers cooperative society limited revealed that on a good season (without inundation), one hectare of land can on average, yield 2.74 tons. This value is not much different from the country-wide rice yields of say 2.84 ton/ ha in 2019 (Knoema 2021). The average cost of a ton is approximately UGX 2,400,000 (US\$ 675). ${ }^{1}$ By adopting these figures, the estimated loss on rice at varying return periods was computed, as shown in Fig. 10.

Destruction of plantations signals a high risk of food insecurity and poverty in the area. In 2019, gardens were destroyed in Tororo and Butaleja district leaving the community in looming fears of famine (Daily Monitor 2019). A similar event happened in 2020 (Uganda Radio Network 2020). With the above, communities may need to develop best management practices such as restoration of wetlands and embracing of cover crops (Antolini et al. 2020). Alternatively, farmers may need to opt cultivating low yielding traditional crops that are rather resistant to flooding instead of experiencing total losses. Besides, observation of flood trends may help famers adjust their agricultural activities in the flood prone areas.

Figure $11 \mathrm{a}, \mathrm{b}$ shows the inundated infrastructures (churches, mosques, academic institutions and health facilities). There was no noticeable difference in the number of inundated infrastructures at the six different return periods $(2,5,10,25,50$ and 100 years). Therefore, in Fig. 11a, b, only results obtained at 100-YRP are presented considering the extreme flow $(\mathrm{Q})$. Considering the 100-YRP, fifteen academic institutions, twelve health facilities were inundated and remain susceptible to future inundation (Fig. 11a). Similarly, twelve mosques and twenty churches are at a risk of flooding (Fig. 11b).

Based on the available information, economic losses due to flooding of infrastructures were estimated following the procedure in Sect. 2.3.4. The estimated economic losses for

\footnotetext{
${ }^{1}$ UGX 3,554 is equivalent to 1 US\$ (approximated based on the Bank of Uganda rate on 23 June 2021). UGX denotes Uganda Shilling and US\$ stands for United States Dollar.
} 
Fig. 10 Cost of inundated rice crops at various return periods
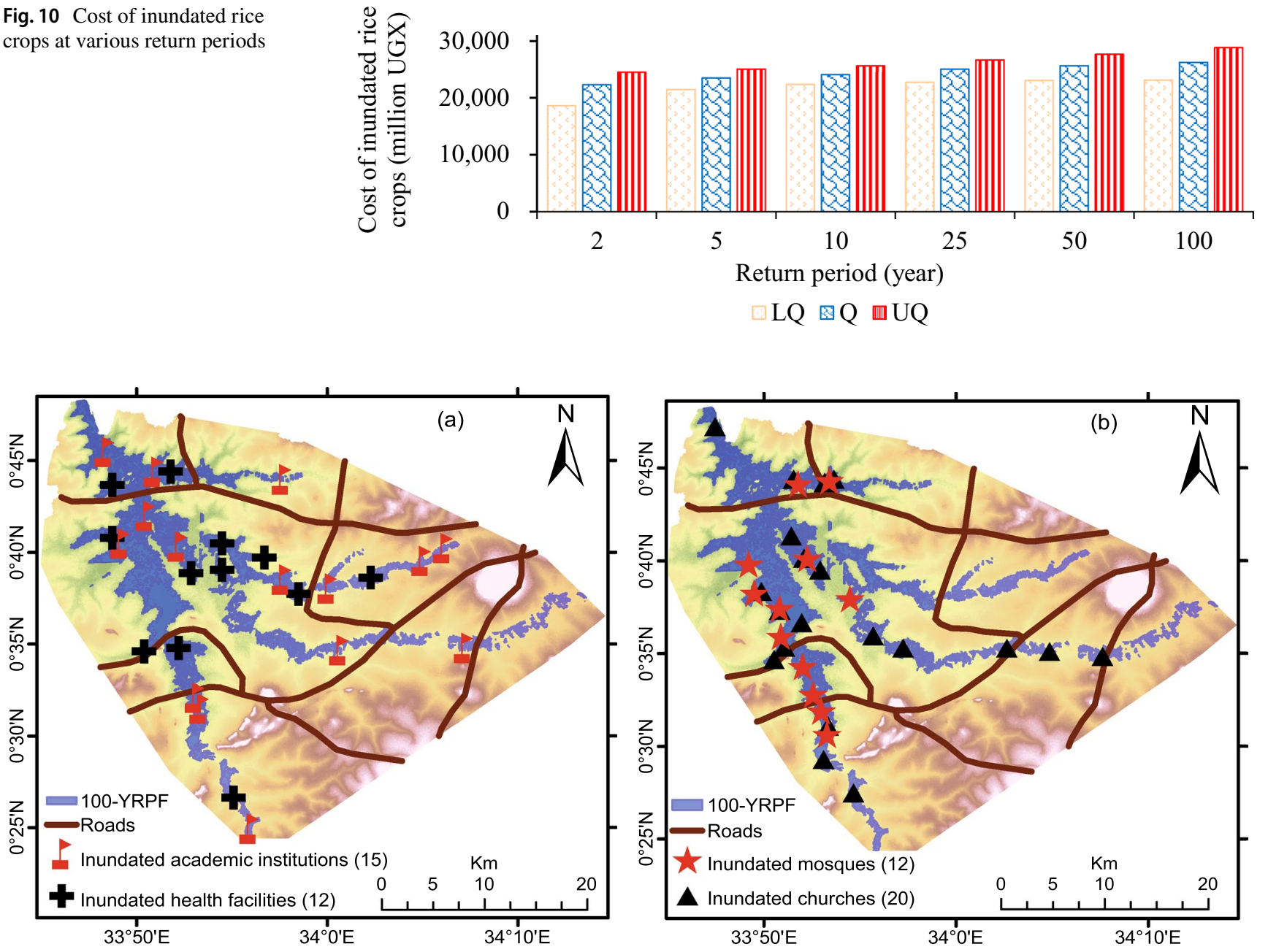

Fig. 11 Inundation extent of a academic institutions, health facilities roads and $\mathbf{b}$ mosques, churches for the 100-YRP obtained using the extreme flows (Q)

Table 5 Flood economic damage losses estimations for the selected infrastructures

\begin{tabular}{lllll}
\hline Infrastructure & \multicolumn{4}{l}{ Economic losses (US\$) } \\
\cline { 2 - 5 } & \multicolumn{4}{l}{ Return period (year) } \\
\cline { 2 - 5 } & 2 & 10 & 50 & 100 \\
\hline Church & 855,065 & $1,059,262$ & $1,130,255$ & $1,623,832$ \\
Academic institutions & 459,741 & 708,104 & 772,855 & $1,116,149$ \\
Mosque & 502,129 & 720,139 & 849,277 & $1,276,465$ \\
Health facilities & 422,597 & 615,545 & 630,842 & 862,034 \\
\hline
\end{tabular}

various infrastructure are indicated in Table 5. Churches exhibited the highest economic losses of US\$ 855,065 and US\$1,623,832 at 2-YRP and 100-YRP, respectively (Table 5). Heath facilities had the least economic losses of US\$ 422,597 and US\$ 862,034 at 2-YRP and 100-YRP, respectively (Table 5). For higher return periods beyond 100 years, the risk needs to be assessed in future when adequate flow data is available. Improvement of catchment management can minimise the inundation of such key infrastructures.

The major transport roads including highway are at a risk of inundation as presented in Fig. 12.

A total of about $4.6 \mathrm{~km}$ and $6.7 \mathrm{~km}$ of road network are prone to inundation considering the LQ and UQ at 2-year return period. At 100-year return period, the affected roads will increase to approximately $6.54 \mathrm{~km}$ and $8.43 \mathrm{~km}$ for LQ and UQ, respectively (Fig. 12). The affected sections of the roads have bridges and/or culverts. Inundation of the road infrastructure indicates probable inadequate capacity of the existing bridges and/or culverts. This puts the roads in danger of collapsing hence disrupting transport and livelihoods in the area. The authorities may use these findings as baseline information in development of more all-inclusive approaches for improving safety of these infrastructures. 
Fig. 12 Estimated inundated roads for 2-100-year return periods

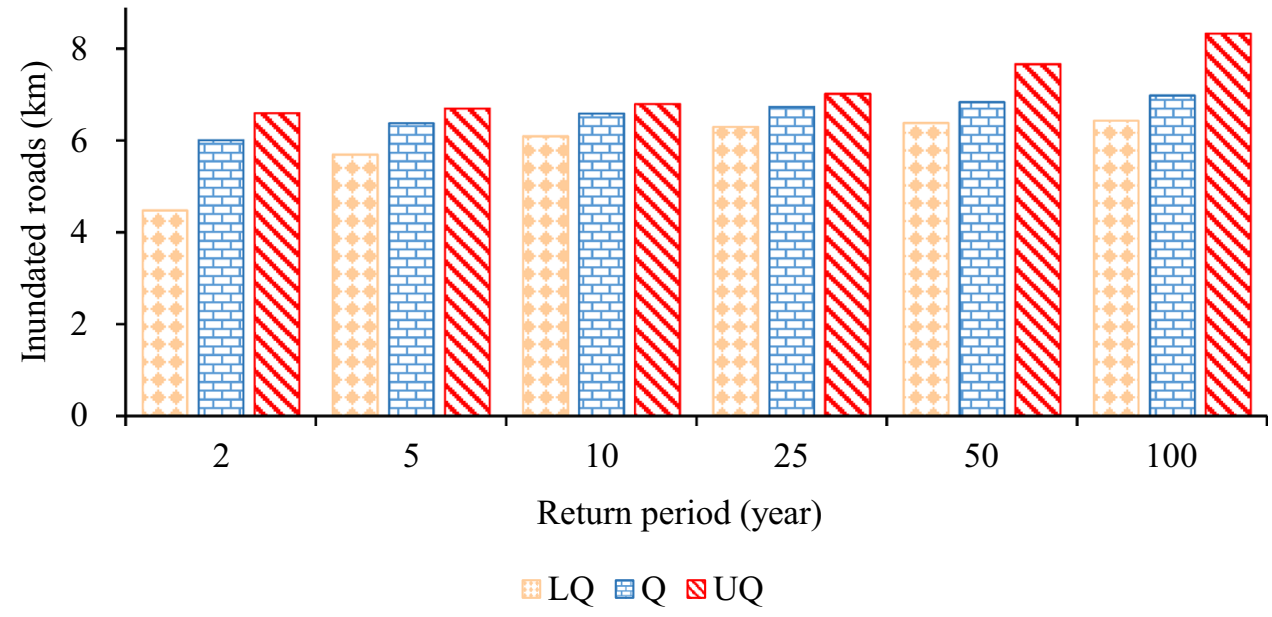

\section{Conclusion}

The study area tends to experience dramatic flooding events, with several socio-economic impacts, such as loss of lives and destructions of physical infrastructure. Performing flood risk assessment is vital for predictive planning of risk-based adaptation measures. In this context, the 2D HEC-RAS model was employed on Ugandan River Malaba sub-catchment. Spatial extent of inundation on human settlement, land cover and several infrastructures were assessed with respect to return periods of extreme flow quantiles. HEC-RAS model results generally confirmed an acceptable fit with the observed data. The changes in LULC from 2010 to 2017 had no significant influence on the flow/flood simulations $(p>0.05)$. Flooding was highly noticeable in the low-lying areas of Butaleja, Tororo and some parts of Namutumba and Bugiri. Cropland was and may continue experiencing the highest vulnerability followed by bare land. Large amounts of money losses are estimated due to inundated rice gardens. This signals a high risk of food insecurity and poverty in the study area. Therefore, fast growing crops and developing best agricultural management practices such as restoration of wetlands and embracing of cover crops could be adopted by farmers. Human settlement and several infrastructures (e.g., churches, mosques, academic institutions, health facilities, roads, etc.) are at a risk flooding. Churches displayed the highest economic loss overall. Therefore, there is need to sensitise the community on the dangers of setting-up structures in flood-prone areas. Besides, authorities should provide land in safe places for setting-up some of the communal infrastructures. In addition, several structural and non-structural sustainable management strategies including embankment/river training structures, flood forecasting and early warning, modification of farming practices, watershed management, relocation of personal property can help in reducing the flood-related loss of human life and property (Mubialiwo et al. 2021a).
A few limitations to this study which form recommendations for future research studies are worth mentioning. Future research studies should consider finer spatial resolution LULC data. Similarly, the use of high-resolution terrain data, for instance, by processing aerial images acquired by unmanned aerial vehicle (UAV) flights over the flood risk area is recommended for future research studies. To eliminate the bias from using assumed damage functions, future research studies are recommended when site-specific damage functions are developed. Besides, future research studies should explore applying flood loss models to estimate crop losses (Pinos et al. 2020; Tanir et al. 2021). Future research studies are recommended to advance the present study findings by performing hybrid 1D-2D model when the overflow locations information become available. This study provides information of the inundation extent and level of vulnerability across the study area which is vital for development of risk-based adaptation pathways. Government authorities can make use of this study findings to identify the modelled floodplains and vulnerability, which can be circulated to the local establishments for effective land-use planning and management.

\section{Appendix}

\section{A. Additional Information on Recent Flooding Events}

See Appendix Table 6. 
Table 6 Some of the recent flooding events that have impacted Uganda (particularly the present study area)

\begin{tabular}{|c|c|c|c|}
\hline $\mathrm{S} / \mathrm{N}$ & Date & Impact & Source \\
\hline 1 & 08 May 2021 & $\begin{array}{l}\text { About } 15,000 \text { families affected, crops destroyed, roads blocked, at } \\
\text { least one person suspected dead }\end{array}$ & (Floodlist 2021) \\
\hline 2 & 15 December 2019 & At least 4 death, over 200 people displaced, houses destroyed, & (Floodlist 2019) \\
\hline 3 & 18 October 2018 & 12,000 people affected, 858 people displaced, 51 death & (Assessment Capacity Project, ACAPS 2018) \\
\hline 4 & 15 May 2012 & 200 families affected, crops destroyed, at least 4 death & (Reliefweb 2012) \\
\hline 5 & 16 March 2010 & 94 death with 300 people missing, 33,000 households affected & $\begin{array}{l}\text { (United Nations Office of the Coordination of } \\
\text { Humanitarian Affairs, OCHA 2010) }\end{array}$ \\
\hline 6 & 09 October 2007 & 300,000 people affected & (Reliefweb 2007) \\
\hline
\end{tabular}

\section{B. Lumped Conceptual Rainfall-Runoff Models}

See Appendix Table 7.

Table 7 Lumped conceptual rainfall-runoff models

\begin{tabular}{lll}
\hline S/N & Model & Source \\
\hline 1 & Australian water balance model (AWBM) & (Boughton 2004) \\
2 & Sacramento (SAC) & (Burnash 1995) \\
3 & TANK & (Sugawara 1995) \\
4 & Identification of Unit Hydrographs and Component Flows from Rainfall, & (Croke et al. 2005; Jakeman et al. 1990) \\
5 & Evaporation and Stream-flow data (IHACRES) & (Porter and McMahon 1971) \\
6 & SIMHYD & (O'Connell et al. 1970) \\
7 & Soil moisture accounting and routing (SMAR) & (Onyutha 2019) \\
\hline
\end{tabular}

\section{Trend Analyses}

Trend magnitude or slope $(m)$ in seasonal and annual rainfall-runoff discharge was calculated using (Theil 1950) and (Sen 1968) as per the following expression:

$m=\operatorname{median}\left(\frac{x_{j}-x_{i}}{j-i}\right), \quad \forall i<j$

where $x_{j}$ and $x_{i}$ are, respectively, the $j$ th and $i$ th value from the sample of size $n$ such that $1<i \leq(n-1)$ and $1<j \leq n$.

The null hypothesis $H_{o}$ (no trend) was tested using the method developed by (Onyutha 2021) such that for a given data set $Y$ of sample size $n$, we can re-scale $Y$ into series $d_{y}$ using

$d_{y, i}=n-w_{y, i}-2 t_{y, i}$ for $1 \leq i \leq n$

where $t_{y, i}$ denotes the number of times the $i$ th observation exceeds other data points in $Y$. In the same line, $w_{y, i}$ refers to number of times the $i$ th data point appears within $Y$.
The trend statistic $T$ was given by (Onyutha 2021)

$T=\sum_{j=1}^{n} \sum_{i=1}^{j} e_{y, i}$

where

$e_{y, i}=d_{y, i} \times \sqrt{(n-1) \times\left(\sum_{i=1}^{n}\left(d_{y, i}\right)^{2}\right)^{-1}}$ for $1 \leq i \leq n$.

The mean of $T$ is zero and for large $n$ the distribution of $T$ is approximately normal with the variance of $T$ or given by (Onyutha 2021)

$V(T)=\frac{n\left(n^{2}-1\right)}{12}$. 
The standardized test statistic $Z$ which follows the standard normal distribution with mean (variance) of zero (one) is given by

$Z=\frac{T}{\sqrt{V(T)}}$

After application of Eq. (C.6) following correction of $V(T)$ from the effect of scaling according to the procedure in Onyutha (2021), the $H_{o}$ (no trend) was rejected for $|Z|>\left|Z_{\alpha / 2}\right|$, where $Z_{\alpha / 2}$ denotes the standard normal variate at the selected $\alpha$; otherwise the $H_{o}$ was not rejected at $\alpha$. In this study, $\alpha$ was taken as 0.05 thereby corresponding with the $Z$ value of 1.96 .

\section{Depth-Damage Functions}

See Appendix Table 8. 


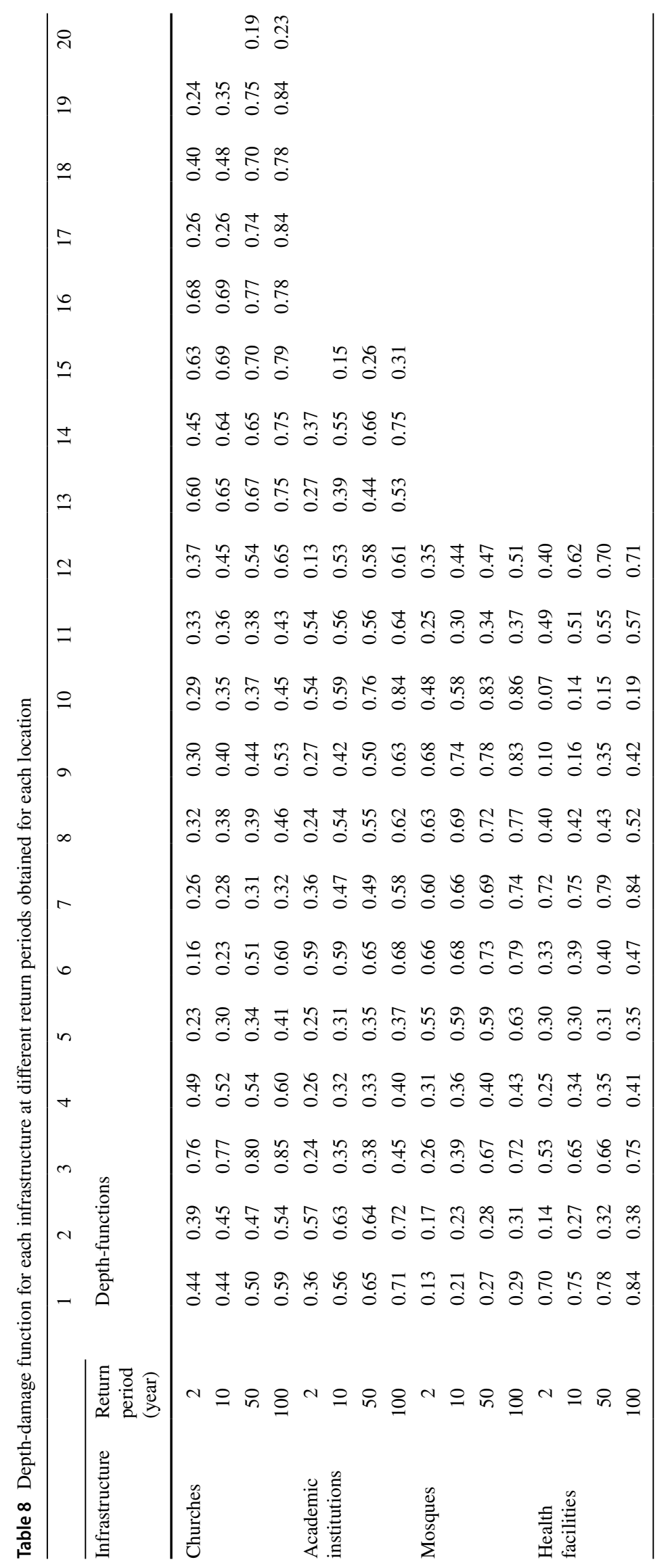




\section{E. Further Information on Flooding Extent on Different Land Cover Types}

See Appendix Fig. 13.

Fig. 13 Flooding extent on different land cover types considering various return periods based on a LQ and b UQ
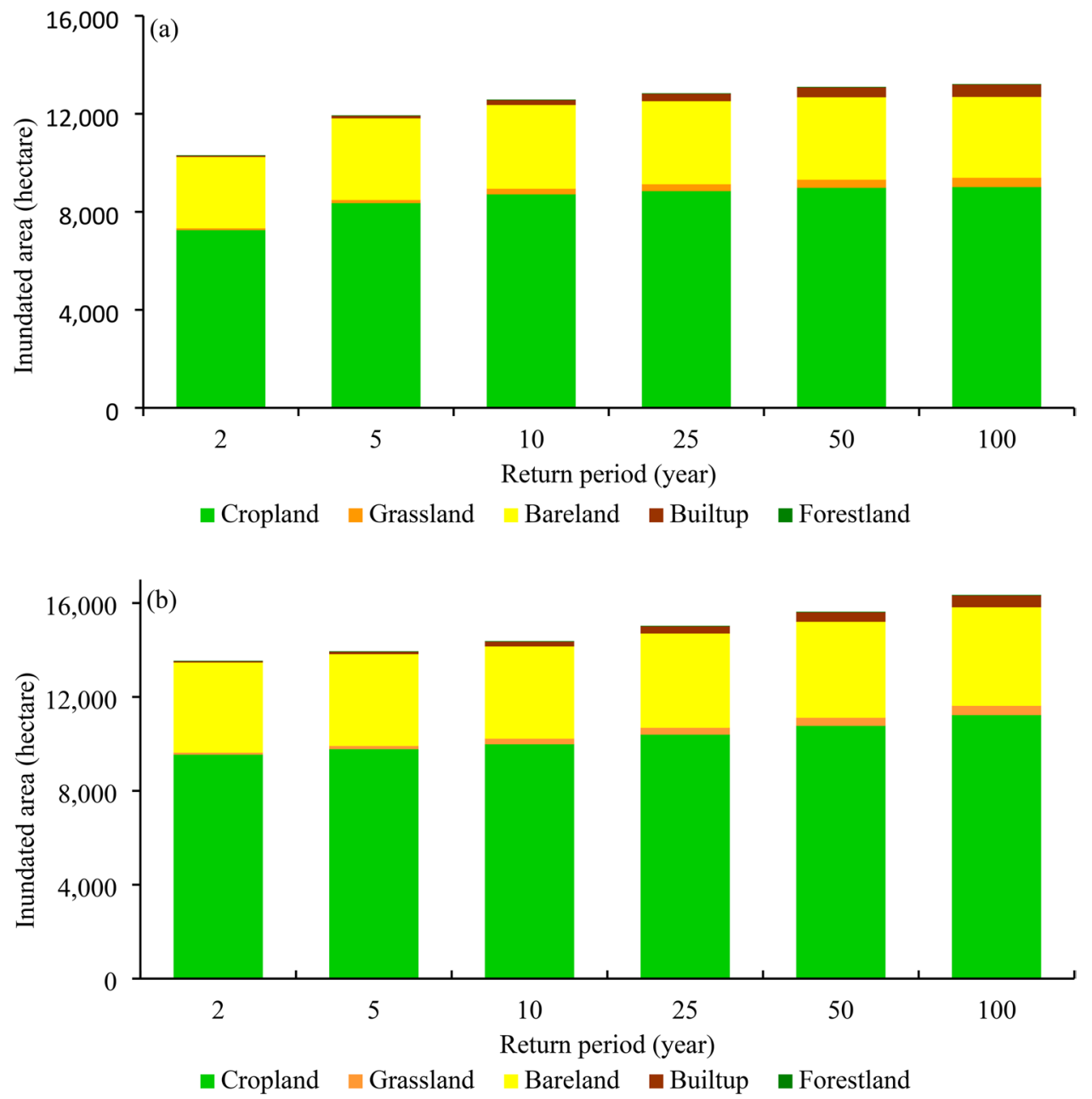

Acknowledgements The authors acknowledge the use of flow data from the previous study (Mubialiwo et al. 2021b). Appreciation is extended to the Uganda National Forest Authority (NFA) for providing land-use map. The digital elevation model used in the paper is available from Alaska Satellite Facility via https://asf.alaska.edu/ data-sets/sar-data-sets/alos-palsar/ (accessed: 10 June, 2021). Data on physical infrastructures was obtained from the Uganda Bureau of Statistics (UBOS). In a special way, authors extend their gratefulness to the Department of Civil and Environmental Engineering, Kyambogo University, Uganda for providing office space and computer laboratory services to the research team. In addition, authors recognise Mr. Andrew Mutenga of Butaleja District Local Government and Mr. Cyrus Chelangat for their support whenever called upon. The authors are indebted to Mr. Enock Kajubi for his substantial contributions, especially during field activities.
Author contributions All authors visualised the study. AM: developed the methodology, collected and analysed the data, and drafted the original manuscript. AA, NSK, JE, SN and CO: reviewed and edited the draft manuscript including refining the grammar. AM: edited the final manuscript. AA and $\mathrm{CO}$ were advisors to AM while conducting the study. In general, this study received combined input from all the authors who read and approved the final manuscript version for submission.

Funding This research was conducted using the financial support through the Ph.D. scholarship awarded to the first author by the Africa Center of Excellence for Water Management, Addis Ababa University, Ethiopia (Grant No. ACEWM/GSR/4334/11).

Data and Materials Availability Data and materials used in this research can be requested and accessed from the corresponding author. 
Code Availability Not applicable.

\section{Declarations}

Conflict of interest Authors of this paper have no financial or nonfinancial interests to disclose.

Ethical approval Not applicable.

Consent to participate Not applicable.

Consent to publication Not applicable.

Open Access This article is licensed under a Creative Commons Attribution 4.0 International License, which permits use, sharing, adaptation, distribution and reproduction in any medium or format, as long as you give appropriate credit to the original author(s) and the source, provide a link to the Creative Commons licence, and indicate if changes were made. The images or other third party material in this article are included in the article's Creative Commons licence, unless indicated otherwise in a credit line to the material. If material is not included in the article's Creative Commons licence and your intended use is not permitted by statutory regulation or exceeds the permitted use, you will need to obtain permission directly from the copyright holder. To view a copy of this licence, visit http://creativecommons.org/licenses/by/4.0/.

\section{References}

Alaska Satellite Facility (2021) Alos Palsar. https://asf.alaska.edu/datasets/sar-data-sets/alos-palsar/. Accessed 11 Apr 2021

Alawamy JS, Balasundram SK, Hanif AHM, Sung CTB (2020) Detecting and analyzing land use and land cover changes in the Region of Al-Jabal Al-Akhdar, Libya using time-series landsat data from 1985 to 2017. Sustainability 12:1-24. https://doi.org/10.3390/ su12114490

Alkema D (2007) Simulating floods on the application of a 2D-hydraulic model for flood hazard and risk assessment. University of Utrecht

Amadio M, Rita Scorzini A, Carisi F, Essenfelder HA, Domeneghetti A, Mysiak J, Castellarin A (2019) Testing empirical and synthetic flood damage models: the case of Italy. Nat Hazards Earth Syst Sci 19:661-678. https://doi.org/10.5194/nhess-19-661-2019

Antolini F, Tate E, Dalzell B, Young N, Johnson K, Hawthorne PL (2020) Flood risk reduction from agricultural best management practices. J Am Water Resour Assoc 56:161-179. https://doi.org/ $10.1111 / 1752-1688.12812$

Apollonio C, Balacco G, Novelli A, Tarantino E, Piccinni AF (2016) Land use change impact on flooding areas: the case study of Cervaro Basin (Italy). Sustainability 8:1-18. https://doi.org/10.3390/ su8100996

Assessment Capacity Project (ACAPS) (2018) Uganda: Flooding and landslides in Bududa. https://www.acaps.org/sites/acaps/files/ products/files/20181018_acaps_start_briefing_note_uganda_ flooding_and_landslides_in_bududa.pdf. Accessed 15 Oct 2020

Barasa B, Kakembo V, Mugagga F, Egeru A (2013) Comparison of extreme weather events and streamflow from drought indices and a hydrological model in River Malaba, Eastern Uganda. Int J Environ Stud 70:940-951. https://doi.org/10.1080/00207233. 2013.862463

Barasa B, Kakembo V, Mwololo Waema T, Laban M (2017) Effects of heterogeneous land use/cover types on river channel morphology in the Solo River catchment, Eastern Uganda. Geocarto Int 32:155-166. https://doi.org/10.1080/10106049.2015.1132480

Bedient BP, Huber CW (2002) Hydrology and floodplain analysis. Prentice-Hall, Upper Saddle River

Beirlant J, Teugels J, Vynckier P (1996) Practical analysis of extreme values. Leuven, University Press, Leuven

BMT-WBM (2018) TUFLOW 1D/2D Fixed Grid Hydraulic Modelling. TUFLOW and TUFLOW HPC hydrodynamic computational engines

Boughton W (2004) The Australian water balance model. Environ Model Softw 19:943-956. https://doi.org/10.1016/j.envsoft.2003. 10.007

Brereton RG (2015) The $\mathrm{t}$-distribution and its relationship to the normal distribution. J Chemom Columnist 29:481-483. https://doi. org/10.1002/cem. 2713

Brunner GW (2016) HEC-RAS, River Analysis System Hydraulic Reference Manual. US Army Corps of Engineers Hydrologic Engineering Center (HEC), Davis, CA

Bucchignani E, Mercogliano P, Panitz H, Montesarchio M (2018) Climate change projections for the Middle East-North Africa domain with COSMO-CLM at different spatial resolutions. Adv Clim Chang Res. https://doi.org/10.1016/j.accre.2018.01.004

Burnash R (1995) The NWS river forecast system-catchment modeling. In: Singh V (ed) Computer models of watershed hydrology. Water Resources Publication, Colorado, pp 311-366

Camberlin P (2009) Nile basin climates. In: Dumont HJ (ed) The Nile: origin, environments, limnology and human use. Springer, Berlin, pp 307-333

Chen J (2007) Flood damage map for the huong river basin. University of Twente, The Netherland

Costabile P, Ostanzo C, Ferraro D, Macchione F, Petaccia G (2020) Performances of the new HEC-RAS version 5 for 2-D hydrodynamic-based rainfall-runoff simulations at basin scale: comparison with a state-of-the art model. Water 12:1-19. https://doi.org/10. 3390/w12092326

Croke B, Andrew F, Spate J, Cuddy S (2005) IHACRES User Guide. Technical Report 2005/19. Second Edition. iCAM, School of Resources, Environment and Society. The Australian National University, Canberra

Daily Monitor (2019) Famine looms as floods ravage gardens in eastern region. https://www.monitor.co.ug/uganda/news/national/famine-looms-as-floods-ravage-gardens-in-eastern-region- 1855692. Accessed 15 June 2021

Deltares systems (2019) SOBEK hydrodynamics rainfall runoff and real time control-user manual. Deltares, Delft

DHI (2017) MIKE 21 Flow Model User Manual. DHI

Dhungel S, Barber ME, Mahler RL (2019) Comparison of oneand two- dimesnional flood modelling in urban environments. Int J Sustain Dev Plan 14:356-366. https://doi.org/10.2495/ SDP-V14-N4-356-366

Floodlist (2019) Uganda-deadly floods and landslides in eastern region (updated). http://floodlist.com/africa/uganda-floodsbududa-sironko-december-2019. Accessed 10 Jan 2020

Floodlist (2021) Uganda-severe flooding affects thousands in Butaleja. http://floodlist.com/africa/uganda-flooding-butalejamay-2021. Accessed 14 June 2021

Garcia M, Juan A, Bedient P (2020) Integrating reservoir operations and flood modeling with HEC-RAS 2D. Water 12:1-8. https://doi. org/10.3390/w12082259

Ghimire E (2019) Evaluation of one-dimensional and two-dimensional HEC-RAS models for flood travel time prediction and damage assessment using HAZUS-MH: a case study of grand river. Youngstown State University, Ohio

Hirabayashi Y, Tanoue M, Sasaki O, Zhou X, Yamazaki D (2021) Global exposure to flooding from the new CMIP6 climate 
model projections. Sci Rep 11:1-7. https://doi.org/10.1038/ s41598-021-83279-w

Höffken J, Vafeidis AT, MacPherson LR, Dangendorf S (2020) Effects of the temporal variability of storm surges on coastal flooding. Front Mar Sci 7:1-14. https://doi.org/10.3389/fmars.2020.00098

Huang Y, Qin X (2014) Uncertainty analysis for flood inundation modelling with a random floodplain roughness field. Environ Syst Res $3: 1-7$

Huizinga J, De Moel H, Szewczyk W (2017) Global flood depth-damage functions: Methodology and the database with guidelines, EUR 28552 EN, Publications Office of the European Union, Luxembourg. https://doi.org/10.2760/16510, JRC105688

Ialongo C (2019) Confidence interval for quantiles and percentiles. Biochem Medica 29:1-13. https://doi.org/10.11613/BM.2019. 010101

Jakeman AJ, Littlewood IG, Whitehead PG (1990) Computation of the instantaneous unit hydrograph and identifiable component flows with application to two small upland catchments. J Hydrol 117:275-300. https://doi.org/10.1016/0022-1694(90)90097-H

Jiang B, Bamutaze Y, Pilesjö P (2014) Climate change and land degradation in Africa: a case study in the Mount Elgon region, Uganda. Geo-Spatial Inf Sci 17:39-53. https://doi.org/10.1080/10095020. 2014.889271

Kangieser PC, Blackadar A (1994) Estimating the likelihood of extreme events. Weatherwise 47:38-40

Kilama Luwa J, Bamutaze Y, Majaliwa Mwanjalolo JG, Waiswa D, Pilesjö P, Mukengere EB (2020) Impacts of land use and land cover change in response to different driving forces in Uganda: evidence from a review. Afr Geogr Rev. https://doi.org/10.1080/ 19376812.2020.1832547

Kitutu MG, Muwanga A, Poesen J, Deckers JA (2009) Influence of soil properties on landslide occurrences in Bududa district, Eastern Uganda. Afr J Agric Res 4:611-620

Kiyengo R, Majaliwa M, Twinomuhangi R, Waswa H (2019) Spatiotemporal flood trends \& settlement choice in flood-prone areas. A case study of Lubiji micro-catchment, Kampala City. Int J Environ Stud. https://doi.org/10.1080/00207233.2019.1686910

Knoema (2021) Uganda - paddy rice yield. https://knoema.com/atlas/ Uganda/topics/Agriculture/Crops-Production-Yield/Paddy-riceyield. Accessed 15 June 2021

Koenig TA, Bruce JL, O’Connor J, McGee BD, Holmes RR, Hollins RJ, Forbes BT, Kohn MS, Schellekens MF, Martin ZW, Peppler MC (2016) Identifing and preserving high-water mark data. In: Surface-Water Techniques Book 3, Applications of Hydraulics. U.S. Geological Survey, Science Information Delivery, Denver, Colorado, p 60

Kumar N, Kumar M, Sherring A, Suryavanshi S, Ahmad A, Lal D (2019) Applicability of HEC-RAS 2D and GFMS for flood extent mapping: a case study of Sangam area, Prayagraj, India. Model Earth Syst Environ. https://doi.org/10.1007/s40808-019-00687-8

Ma Z, Liu Z, Zhao Y, Zhang L, Liu D, Ren T, Zhang I, Li S (2020) An unsupervised crop classification method based on principal components isometric binning. Int J Geo Inf 9:124. https://doi. org/10.3390/ijgi9110648

Martínez-Gomariz E, Forero-Ortiz E, Guerrero-Hidalga M, Castán S, Gómez M (2020) Flood depth-damage curves for Spanish urban areas. Sustainability 12:1-25. https://doi.org/10.3390/su12072666

Mayega RW, Tumuhamye N, Atuyambe L, Okello D, Bua G, Ssentongo J, Bazeyo W (2015) Qualitative Assessment of Resilience to the Effects of Climate Variability in the Three Communities in Uganda. RAN Secretariat and East African Resilience Innovation Lab (EA RILab), Kampala

McGrath H, Abo El Ezz A, Nastev M (2019) Probabilistic depth-damage curves for assessment of flood-induced building losses. Nat Hazards 97:1-14. https://doi.org/10.1007/s11069-019-03622-3
Ministry of Water and Environment (2014) Uganda Second National Communication to the United Nations Framework Convention on Climate Change. Kampala

Ministry of Water and Environment (2018) Mpologoma Catchment Management Plan. Ministry of Water and Environment, Kampala

Molinari D, Rita Scorzini A, Arrighi C, Carisi F, Castelli F, Domeneghetti A, Gallazzi A, Galliani M, Grelot F, Kellermann P, Kreibich H, Mohor GS, Mosimann M, Natho S, Richert C, Schroeter K, Thieken AH, Paul Zischg A, Ballio F (2020) Are flood damage models converging to "reality"? Lessons learnt from a blind test. Nat Hazards Earth Syst Sci 20:2997-3017. https://doi. org/10.5194/nhess-20-2997-2020

Mubialiwo A, Onyutha C, Abebe A (2020) Historical rainfall and evapotranspiration changes over mpologoma catchment in Uganda. Adv Meteorol 2020:1-19. https://doi.org/10.1155/2020/8870935

Mubialiwo A, Abebe A, Onyutha C (2021a) Analyses of community willingness-to-pay and the influencing factors towards restoration of River Malaba floodplains. Environ Challenges 4:1-14. https:// doi.org/10.1016/j.envc.2021.100160

Mubialiwo A, Abebe A, Onyutha C (2021b) Performance of rainfallrunoff models in reproducing hydrological extremes: a case of the River Malaba sub-catchment. SN Appl Sci 3:24. https://doi.org/ 10.1007/s42452-021-04514-7

Mubialiwo A, Chelangat C, Onyutha C (2021c) Changes in precipitation and evapotranspiration over Lokok and Lokere catchments in Uganda. Bull Atmos Sci Technol 2:1-23. https://doi.org/10.1007/ s42865-021-00031-y

Najibi N, Devineni N (2018) Recent trends in the frequency and duration of global floods. Earth Syst Dyn 9:757-783. https://doi.org/ 10.5194/esd-9-757-2018

Neema S, Mongo Bua G, Tuhebwe D, Ssentongo J, Tumuhamye N, Mayega RW, Fishkin J, Atuyambe LM, Bazeyo W (2018) Community perspective on policy options for resettlement management: a case study of risk reduction in Bududa, Eastern Uganda. PLOS Curr Disasters. https://doi.org/10.1371/currents.dis.49e8e 547de25ca1c1f9edbbfc8b9efa5

O'Connell PE, Nash JE, Farrell JP (1970) River flow forecasting through conceptual models part II-the brosna catchment at Ferbane. J Hydrol 10:317-329. https://doi.org/10.1016/00221694(70)90221-0

OCHA (2010) Eastern Uganda Landslides and Floods Situation Report\#3. https://reliefweb.int/sites/reliefweb.int/files/resou rces/81D1CDAB49713514C12576EA003098A5-Full_Report. pdf. Accessed 3 Oct 2020

Ongdas N, Akiyanova F, Karakulov Y, Muratbayeva A, Zinabdin N (2020) Application of HEC-RAS (2D ) for flood hazard maps generation for Yesil (Ishim) river in Kazakhstan Nurlan. Water 12:20. https://doi.org/10.3390/w12102672

Onyutha C (2019) Hydrological model supported by a step-wise calibration against sub-flows and validation of extreme flow events. Water 11(244):1-23. https://doi.org/10.3390/w11020244

Onyutha C (2021) Graphical-statistical method to explore variability of hydrological time series. Hydrol Res 52:266-283. https://doi. org/10.2166/nh.2020.111

Onyutha C, Willems P (2013) Uncertainties in flow-duration-frequency relationships of high and low flow extremes in Lake Victoria Basin. Water 5:1561-1579. https://doi.org/10.3390/w5041561

Onyutha C, Willems P (2015) Empirical statistical characterization and regionalization of amplitude-duration-frequency curves for extreme peak flows in the Lake Victoria Basin, East Africa. Hydrol Sci J 60:997-1012. https://doi.org/10.1080/02626667. 2014.898846

Onyutha C, Acayo G, Nyende J (2020) Analyses of precipitation and evapotranspiration changes across the Lake Kyoga Basin in East Africa. Water 12:1-23. https://doi.org/10.3390/w12041134 
Onyutha C, Asiimwe A, Ayugi B, Ngoma H, Ongoma V, Tabari H (2021a) Observed and future precipitation and evapotranspiration in water management zones of uganda: Cmip6 projections. Atmosphere (basel) 12:1-25. https://doi.org/10.3390/atmos12070887

Onyutha C, Asiimwe A, Muhwezi L, Mubialiwo A (2021b) Water availability trends across water management zones in Uganda. Atmos Sci Lett. https://doi.org/10.1002/asl.1059

Onyutha C, Nyesigire R, Nakagiri A (2021c) Contributions of human activities and climatic variability to changes in River Rwizi Flows in Uganda, East Africa. Hydrology 8:145. https://doi.org/10.3390/ hydrology 8040145

Onyutha C, Turyahabwe C, Kaweesa P (2021d) Impacts of climate variability and changing land use/land cover on River Mpanga flows in Uganda, East Africa. Environ Challenges 5:1-14. https:// doi.org/10.1016/j.envc.2021.100273

Osuret J, Atuyambe LM, Mayega RW, Ssentongo J, Tumuhamye N, Bua GM, Tuhebwe D, Bazeyo W (2016) Coping strategies for landslide and flood disasters: a qualitative study of Mt. Elgon Region, Uganda. PLOS Curr Disasters. https://doi.org/10.1371/ currents.dis.4250a225860babf3601a18e33e172d8b

Padulano R, Rianna G, Costabile P, Costanzo C, Del G, Mercogliano $\mathrm{P}$ (2021) Propagation of variability in climate projections within urban flood modelling: a multi-purpose impact analysis. J Hydrol 602:18. https://doi.org/10.1016/j.jhydrol.2021.126756

Pinos J, Timbe L (2019) Performance assessment of two-dimensional hydraulic models for generation of flood inundation maps in mountain river basins. Water Sci Eng 12:11-18. https://doi.org/ 10.1016/j.wse.2019.03.001

Pinos J, Orellana D, Timbe L (2020) Assessment of microscale economic flood losses in urban and agricultural areas: case study of the Santa Bárbara River, Ecuador. Nat Hazards 103:2323-2337. https://doi.org/10.1007/s11069-020-04084-8

Porter JW, McMahon TA (1971) A model for the simulation of Streamflow data from climatic records. J Hydrol 13:297-324

Ramiaramanana FN, Teller J (2021) Urbanization and floods in subsaharan africa: Spatiotemporal study and analysis of vulnerability factors - case of antananarivo agglomeration (Madagascar). Water 13:1-23. https://doi.org/10.3390/w13020149

Rangari VA, Umamahesh NV, Bhatt CM (2019) Assessment of inundation risk in urban floods using HEC RAS 2D. Model Earth Syst Environ. https://doi.org/10.1007/s40808-019-00641-8

Reliefweb (2007) Uganda: Floods OCHA Situation Report No. 7. OCHA. https://reliefweb.int/report/uganda/uganda-floods-ochasituation-report-no-7

Reliefweb (2012) Floods ravage gardens in Tororo. OCHA. https://relie fweb.int/report/uganda/floods-ravage-gardens-tororo

Reliefweb (2019) Floods, landslides: Gov't speaks out on disaster situation. https://reliefweb.int/report/uganda/floods-landslides-govtspeaks-out-disaster-situation. Accessed 14 June 21

Reliefweb (2020) Map showing Districts Affected by the February, March, April and May (MAM) Rainy Season (Flood and Landslide Prone) including Landing Sites/Lake shores which have experienced rising water levels as of 6th May 2020. https://reliefweb. $\mathrm{int} / \mathrm{map} /$ uganda/map-showing-districts-affected-february-marchapril-and-may-mam-rainy-season-flood-and. Accessed 26 June 21

Romali NS, Yusop Z (2021) Flood damage and risk assessment for urban area in Malaysia. Hydrol Res 52:142-159. https://doi.org/ 10.2166/nh.2020.121

Sampson CC, Smith AM, Bates PD, Neal JC, Alfieri L, Freer JE (2015) A high-resolution global flood hazard model. Water Resour Res. https://doi.org/10.1002/2015WR016954

Sarchani S, Seiradakis K, Coulibaly P, Tsanis I (2020) Flood inundation mapping in an ungauged basin. Water 12:1-21. https://doi. org/10.3390/W12061532
Scorzini AR, Frank E (2017) Flood damage curves: new insights from the 2010 flood in Veneto, Italy. J Flood Risk Manag 10:381-392. https://doi.org/10.1111/jfr3.12163

Sen PK (1968) Estimates of the regression coefficient based on Kendall's tau. J Am Stat Assoc 63:1379-1389. https://doi.org/10.1080/ 01621459.1968.10480934

Shustikova I, Domeneghetti A, Neal JC, Bates P, Castellarin A (2019) Comparing 2D capabilities of HEC-RAS and LISFLOOD-FP on complex topography. Hydrol Sci J 64:1769-1782. https://doi.org/ 10.1080/02626667.2019.1671982

Sugawara M (1995) Tank model. In: Singh VP (ed) Computer models of watershed hydrology. Water Resources Publications, Littleton, pp 165-214

Sule BF, Alabi SA (2013) Application of synthetic unit hydrograph methods to construct storm hydrographs. Int J Water Resour Environ Eng 5:639-647. https://doi.org/10.5897/IJWREE2013.0437

Szwagrzyk M, Kaim D, Price B, Wypych A, Grabska E, Kozak J (2018) Impact of forecasted land use changes on flood risk in the Polish Carpathians. Nat Hazards 94:227-240. https://doi.org/10. 1007/s11069-018-3384-y

Tanir T, Lima ADSD, Coelho GDA, Uzun S, Cassalho F, Ferreira CM (2021) Assessing the spatiotemporal socioeconomic flood vulnerability of agricultural communities in the Potomac River Watershed. Nat Hazards. https://doi.org/10.1007/s11069-021-04677-x

Teng J, Jakeman AJ, Vaze J, Croke BFW, Dutta D, Kim S (2017) Flood inundation modelling: a review of methods, recent advances and uncertainty analysis. Environ Model Softw 90:201-216. https:// doi.org/10.1016/j.envsoft.2017.01.006

Theil H (1950) A rank-invariant method of Linear and Polynomial regression analysis, in: Nederlandse Akademie van Wetenschappen, Series A, A. Statistical Department of the Mathematisch Centrum, Amsterdam, Netherlands, pp 386-392

Uganda Bureau of Statistics (2018) Uganda Bureau of Statistics: Statistical Abstract. Kampala, Uganda

Uganda Bureau of Statistics (2020) Uganda Bureau of Statistics 2020 statistical abstract. Uganda Bur. Stat. https://www.ubos.org/wpcontent/uploads/publications/11_2020STATISTICAL_ABSTR ACT_2020.pdf. Accessed 24 Nov 2020

Uganda Radio Network (2020) Floods Destroy Crop Gardens in Butaleja. https://ugandaradionetwork.net/story/floods-destroycrop-gardens-in-butaleja. Accessed 15 June 2021

Willems P, Guillou A, Beirlant J (2007) Bias correction in hydrologic GPD based extreme value analysis by means of a slowly varying function. J Hydrol 338:221-236. https://doi.org/10.1016/j.jhydr ol.2007.02.035

Xu X, Wang Y, Kalcic M, Logsdon R, Yang YCE, Scavia D (2017) Evaluating the impact of climate change on fl uvial fl ood risk in a mixed-used watershed. Environ Model Softw. https://doi.org/10. 1016/j.envsoft.2017.07.013

Zarekarizi M, Srikrishnan V, Keller K (2020) Neglecting uncertainties biases house-elevation decisions to manage riverine flood risks. Nat Commun 11:1-11. https://doi.org/10.1038/ s41467-020-19188-9

Zope PE, Eldho TI, Jothiprakash V (2016) Impacts of land use-land cover change and urbanization on flooding: a case study of Oshiwara River Basin in Mumbai, India. CATENA 145:142-154. https://doi.org/10.1016/j.catena.2016.06.009 